\title{
Seasonal Considerations for Year-Round Operation of On-Farm Wetlands in Temperate Climates: A Review
}

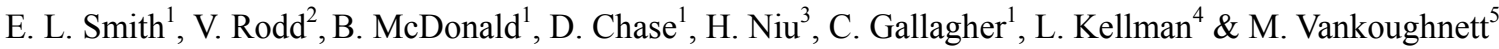 \\ ${ }^{1}$ Agriculture and Agri-Food Canada, Bible Hill, NS, Canada \\ ${ }^{2}$ Agriculture and Agri-Food Canada, Charlottetown, PE, Canada \\ ${ }^{3}$ Faculty of Agriculture, Dalhousie University, Truro, NS, Canada \\ ${ }^{4}$ St. Francis Xavier University, Antigonish, NS, Canada \\ ${ }^{5}$ Nova Scotia Community College, Middleton, NS, Canada \\ Correspondence: E. L. Smith, Agriculture and Agri-Food Canada, 361 Pictou Road, Bible Hill, NS, B2N 2T6, \\ Canada. E-mail: erin.smith2@agr.gc.ca
}

Received: August 16, 2021 Accepted: October 4, $2021 \quad$ Online Published: November 15, 2021

doi:10.5539/jas.v13n12p1 URL: https://doi.org/10.5539/jas.v13n12p1

\begin{abstract}
On-farm constructed wetlands $(\mathrm{CW})$ have been increasing in application over the past several decades to treat a variety of agricultural wastewaters. These systems have been found to be relatively low cost, require minimal maintenance, and provide a very efficient and sustainable means of treating harmful contaminants during the warm seasons before reaching nearby waterways. With farm size increasing in many regions and more waste being generated, it becomes increasingly important to have a viable means of treating wastewaters on a year-round basis. However, temperate climates can present challenges in the treatment of these wastewaters. This paper aims to bring together and review previous research on the use of CWs for treating agricultural wastewater in temperate climates where below freezing temperatures can exist. Focus is placed on the use of various wetland designs, wastewater types, management practices, maintenance, operational challenges and overall treatment capacities. This study highlights the need to carefully consider several factors (i.e., waste type, design, climate, vegetation, management) before using these systems for year-round treatment. Continued research in wetland management will be key in getting wide scale adoption from the agricultural community in temperate climates.
\end{abstract}

Keywords: agriculture, constructed wetlands, temperate climate, treatment efficiencies, wastewater

\section{Introduction}

The use of constructed wetlands $(\mathrm{CW})$ has increased over the past several decades as a means of treating various types of on-farm wastewater. In addition to treating wastewater, the use of CWs has shown many additional benefits. These systems are known to be relatively low cost, require minimal maintenance, help promote biodiversity, and are aesthetically pleasing on the agricultural landscape (Smith et al., 2019). A potential downside to these systems is that they can require a relatively large land base to construct in an on-farm situation depending on the amount of waste to be treated. At times, land may need to be taken out of agricultural production to construct a wetland system. Regardless, these systems are deemed highly efficient at treating wastewater when properly managed.

The treatment capacity of CWs depends largely on adapting the design to the climatic conditions for the local area, understanding the wastewater to be treated, the volume of waste, determining a proper hydraulic loading rate (HLR), and conducting regular water sampling at both the inlet and outlets to ensure local discharge guidelines are being met. The weather variability in colder climate regions such as Atlantic Canada (1981-2010: $1.6^{\circ} \mathrm{C}$ min. and $10.3^{\circ} \mathrm{C}$ max temperatures) (ECCC, 2021) can pose challenges when trying to manage these systems effectively, particularly in winter. Hot dry periods experienced primarily during the summer months can also result in a significant amount of evapotranspiration from these systems. Evapotranspiration processes have the potential to produce increased greenhouse gas emissions (GHG) contributing to global warming. The evapotranspiration process can help eliminate the volume of wastewater to be treated, but it puts more stress on vegetation and the inhabiting biological organisms (Hunt \& Poach, 2001). Intensive wet periods, which occur mainly during the spring and fall months, can also cause accelerated flow and decrease overall retention times 
(RTs), resulting in a more highly concentrated effluent (Thorén et al., 2004). Very cold periods during the winter months in northern regions have been faced with the challenge of complete freeze up where treatment through biological processes is no longer possible (Munoz et al., 2006).

Constructed wetlands have been found to be very effective at treating many different wastewater types such as; sewage (Mæhlum \& Stålnacke, 1999; Nelson et al., 1999; Steinmann et al., 2003; Jessen et al., 2005; Song et al., 2006; Avsar et al., 2007; Llorens et al., 2009; Li et al., 2011; Pedescoll et al., 2011; Wu et al., 2011; Garfi et al., 2012; Gunes et al., 2012; Huang et al., 2013; Li et al., 2014; Vymazal \& Březinová, 2014; Wu et al., 2014), manure runoff (Sievers, 1997; Dunne et al., 2005; Gottschall et al., 2007; Lee et al., 2014), dairy washwater (Phipps \& Crumpton, 1994; Knight et al., 1999; Newman et al., 1999; Schaafama et al., 1999; Kern et al., 2000; Hunt \& Poach, 2001; Braskerud, 2002; Koskiaho et al., 2003; Dunne et al., 2005; Smith et al., 2005b, 2005a; Munoz et al., 2006; Smith et al., 2006; Mustafa et al., 2009; Comino et al., 2011; Kato et al., 2013; Harada et al., 2015), fish farm effluent (Ouellet-Plamondon et al., 2006), greenhouse wastewater (Wood et al., 1999), industrial wastewater (Maine et al., 2007), turf (Reuter et al., 1992) and agricultural tile drainage water (Badiou et al., 2011; McKenna et al., 2020). Challenges can arise when the warm weather adapted systems are used in colder climates year-round. Agricultural wastewater is a year-round issue for many producers; therefore, producers require a year-round solution. It is important to understand the challenges and limitations and to learn how to properly manage these systems so that they can be effectively utilized year-round, especially during cold months in temperate climatic zones.

Studies have been published on wetland design, construction and their capacity for treatment in warm climates. To our knowledge, a limited number of papers have provided a thorough review of their operational considerations in temperate climates where many challenges can arise. Of these few studies even less place primary focus on agricultural wastewater and the unique challenges these wastes present for treatment systems. The primary objective of this paper was to review previous research on the use of CWs for agricultural wastewater treatment in temperate climates. Focus is placed on the use of different wetland designs, wastewater, wetland types, management practices, maintenance and how the various challenges can impact overall treatment capacities. By analyzing effective wetland practices and determining the areas where information is lacking, future research can focus on further enhancing wetland function in cold climates. This in turn will lead to increased treatment efficiencies and higher adoption rates of these systems for agricultural application.

\section{Constructed Wetlands for Wastewater Treatment}

\subsection{Agricultural Wastewater}

Table 1 provides a summary of CWs used in various temperate climates that treat a wide range of agricultural wastewaters. The treatment efficiencies for these $\mathrm{CWs}$ demonstrated how each functioned under the wide temperature ranges. To better understand how each of these systems function, an in-depth review of wetland function in temperate climates is presented. 
Table 1 . Summary of agricultural CWs treating various wastewaters in temperate climates

\begin{tabular}{|c|c|c|c|c|c|c|c|c|c|c|c|c|c|c|c|c|}
\hline \multirow{2}{*}{ Reference } & \multirow{2}{*}{ Study location } & \multirow{2}{*}{ Waste type } & \multirow{2}{*}{$\begin{array}{l}\text { Type of } \\
\text { CW }\end{array}$} & \multirow{2}{*}{ Length of study } & \multirow{2}{*}{ HRT } & \multirow{2}{*}{ HLR } & \multicolumn{10}{|c|}{ Treatment efficiencies (\%) } \\
\hline & & & & & & & BOD $_{5}$ & TSS & TP & TKN & COD & $\mathrm{NH}_{4}{ }^{+}$ & SRP & $\mathbf{N H}_{4}^{+} \mathbf{N}$ & $\mathrm{NO}_{3}^{-}$ & $\mathbf{T N}$ \\
\hline Beutel et al., 2009 & Washington, USA & $\begin{array}{l}\text { field, livestock } \\
\text { runoff }\end{array}$ & $\mathrm{SF}$ & $\begin{array}{l}\text { 2003-2006 } \\
\text { May-Oct. }\end{array}$ & $8 \mathrm{~d}$ & - & - & - & - & - & - & - & - & - & $90-93$ & $57-63$ \\
\hline \multirow{2}{*}{ Bosak et al., 2016} & \multirow{2}{*}{ Alliston, ON } & potato & \multirow{2}{*}{$\mathrm{SF}$} & 2009-2012 Mar.-Jul. & $4.4 \mathrm{mo}$ & - & $86-92$ & 98-99 & $80-91$ & - & - & $20-75$ & - & - & - & $46-51$ \\
\hline & & washwater & & Oct.-Feb. & $3.7 \mathrm{mo}$ & - & NA- 85 & NA-95 & NA-10 & - & - & NA-49 & - & - & - & NA-73 \\
\hline Braskerud, 2002 & Norway & field runoff & $\mathrm{SF}$ & $3-7 \mathrm{yrs}$ & - & - & - & - & $20-44$ & - & - & - & - & - & - & $3-15$ \\
\hline Comino et al., 2011 & Italy & $\begin{array}{l}\text { milkhouse } \\
\text { washwater }\end{array}$ & hybrid & Dec. 07-Feb. 10 & $4-15 d$ & $0.05 \mathrm{~m}^{3} \mathrm{~m}^{-2} \mathrm{~d}^{-1}$ & 80 & 80 & - & - & 80 & - & - & - & - & - \\
\hline Dunne et al., 2005 & Ireland & dairy & $\mathrm{SF}$ & Apr. 01-Sept. 03 & - & - & - & - & - & - & - & - & $5-84$ & - & - & - \\
\hline Gorra et al., 2014 & Aosta Valley, Italy & dairy & SSF & 2003-2005 & $8 \mathrm{~d}$ & $44 \mathrm{~m}^{3} \mathrm{~m}^{-2} \mathrm{~d}^{-1}$ & 92 & - & 40 & - & - & 17 & - & - & - & 27 \\
\hline $\begin{array}{l}\text { Gottschall } \\
\text { et al., } 2007\end{array}$ & Eastern ON & dairy & FWS & 2003-2004 & $112 \mathrm{~d}$ & - & - & - & 58 & 72 & - & 82 & - & - & - & - \\
\hline Harada et al., 2015 & Hokkaido, Japan & milkhouse & hybrid & $6 \mathrm{yrs}$ & - & - & 93.3 & - & 75.5 & - & - & - & - & 77.5 & - & 84.9 \\
\hline \multirow{3}{*}{ Hunt et al., 2001} & Indiana, USA & \multirow{3}{*}{ dairy } & & & - & - & 79 & 72 & 74 & 64 & - & - & - & - & - & - \\
\hline & Oregon, USA & & & & - & - & 61 & 73 & 66 & 57 & 47 & - & - & - & - & - \\
\hline & Mississippi, USA & & & & - & - & 75 & 64 & 61 & - & - & - & - & - & - & - \\
\hline Kato et al., 2013 & Hokkaido, Japan & $\begin{array}{l}\text { dairy, pig, potato } \\
\text { washwater }\end{array}$ & hybrid & Nov. 05 -Nov. 10 & - & - & - & - & $70-93$ & - & $70-96$ & $36-82$ & - & - & - & $39-90$ \\
\hline \multirow{2}{*}{ Kern et al., 2000} & \multirow{2}{*}{ East Germany } & \multirow{2}{*}{ dairy } & \multirow{2}{*}{ SSF } & Summer & $7 \mathrm{~d}$ & $0.013 \mathrm{~m}^{3} \mathrm{~m}^{-2} \mathrm{~d}^{-1}$ & - & - & - & - & 89 & - & - & 99 & - & - \\
\hline & & & & Winter & $7 \mathrm{~d}$ & $0.010 \mathrm{~m}^{3} \mathrm{~m}^{-2} \mathrm{~d}^{-1}$ & - & - & - & - & 92 & - & - & 69 & - & - \\
\hline \multirow{3}{*}{$\begin{array}{l}\text { Koskiaho } \\
\text { et al., } 2003\end{array}$} & \multirow{3}{*}{ Finland } & & & & $39 \mathrm{hrs}$ & - & - & 44 & 50 & - & - & - & - & 26 & - & 37 \\
\hline & & field & $\mathrm{SF}$ & 1998-2001 & $6 \mathrm{hrs}$ & - & - & 16 & 8 & - & - & - & - & -17 & - & -6 \\
\hline & & & & & $>24 \mathrm{hrs}$ & - & - & 18 & 11 & - & - & - & - & 49 & - & 12 \\
\hline Lee et al., 2014 & Nonsan, Korea & piggery & $\mathrm{SF}$ & Oct. 08-Dec. 12 & $48 \mathrm{hrs}$ & - & - & - & - & - & - & 27 & - & - & - & 20 \\
\hline Mantovi et al., 2003 & Casina, Italy & $\begin{array}{l}\text { dairy, } \\
\text { domestic }\end{array}$ & SSF & Oct. 08-Dec. 12 & $26 \mathrm{mo}$ & - & 93.7 & 90.8 & 60.6 & 48.5 & 91.9 & 79.1 & - & - & - & - \\
\hline $\begin{array}{l}\text { Mejia-Franco } \\
\text { et al., } 2020\end{array}$ & Winchester, ON & dairy & $\mathrm{SF}$ & May-Nov. & $\begin{array}{l}15.3-149 \mathrm{~d} \\
9-25 \mathrm{~d} \\
\end{array}$ & $\begin{array}{l}{ }^{*} \mathrm{P} 1: 0.7-7.1 \mathrm{~m}^{3} \mathrm{~d}^{-1} \\
{ }^{*+} \mathrm{W}: 1.2-7.9 \mathrm{~m}^{3} \mathrm{~d}^{-1}\end{array}$ & 67 & 28 & 45 & - & 66 & 65 & - & - & 42 & 64 \\
\hline Mustafa et al., 2009 & Dunhill, Ireland & dairy & $\mathrm{SF}$ & 2001-2007 & - & - & 97.6 & 93.7 & - & - & 94.9 & - & - & - & - & - \\
\hline $\begin{array}{l}\text { Newman } \\
\text { et al., } 1999\end{array}$ & Connecticut, USA & milkhouse & $\mathrm{SF}$ & Aug. 94-Jan. 97 & $41 \mathrm{~d}$ & - & 76 & 94 & 45 & 28 & - & - & - & - & 67 & - \\
\hline Rozema et al., 2016 & Niagara-on- & winery, & VF SSF & 6 yrs GS: May-Oct. & - & - & - & 98.0 & - & 88.7 & 98.9 & 72.7 & - & - & - & - \\
\hline & the-Lake, ON & domestic & & NGS: Nov.-Apr. & - & - & - & 97.7 & - & 98.8 & 98.9 & 98.2 & - & - & - & - \\
\hline $\begin{array}{l}\text { Schaafsma } \\
\text { et al., } 1999\end{array}$ & Maryland, USA & dairy & $\mathrm{SF}$ & Sept. 95-May 97 & 6 wks & - & 97 & 96 & 96 & - & - & 56 & - & - & 82 & 98 \\
\hline Sharma et al., 2013 & Hokkaido, Japan & dairy & hybrid SSF & Nov. 06-Oct. 10 & - & - & 89 & 95 & 72 & - & 89 & - & - & - & - & 76 \\
\hline Sievors 1097 & Columbia MO & nigorey & $\mathrm{SF}$ & Jan 93 Dec 94 & - & - & $18-42$ & $29-49$ & $10-19$ & - & - & $26-40$ & - & - & - & - \\
\hline Sievers, 1997 & Columbia, MO & piggery & SSF & Jan. 93-Dec. 94 & - & - & $22-50$ & $31-42$ & $16-27$ & - & - & $16-37$ & - & - & - & - \\
\hline Swith etal 2005 a & Athentic Conod & dairy & $\mathrm{SE}$ & Apr. 1-Apr. 3001 & - & - & $98.7-99.7$ & $88-95.5$ & $91.2-98.3$ & $91.4-98.8$ & - & $95.6-99.7$ & $95.4-99.5$ & 99.0 & $83.5-86$ & - \\
\hline Smith et al., 2005a & Atlantic Canada & darry & $\mathrm{SF}$ & Jan. 1-Jan. 3002 & - & - & $97-99$ & $89.9-94.5$ & $87.7-89$ & $96-96.8$ & - & 98.6-98.9 & $85.7-87.4$ & 99.0 & $90.7-91.2$ & - \\
\hline Smith et al., 2005b & Atlantic Canada & dairy & $\mathrm{SF}$ & $\begin{array}{l}\text { Nov. 00-Mar. } 02 \\
\text { Winter }\end{array}$ & $95 \mathrm{~d}$ & - & - & - & - & - & - & - & - & $99.6-99.7$ & - & - \\
\hline & & & & Summer & $95 \mathrm{~d}$ & - & - & - & - & - & - & - & - & $99.7-99.8$ & - & - \\
\hline Smith et al 2006 & Athantic Conodr & daing & $\mathrm{SE}$ & Nor $00-M a r 0 ?$ & $15-17.5 \mathrm{~d}$ & $300 \mathrm{Ld}^{-1}$ & 98-99 & $90-97$ & $84-91$ & - & - & $98-99$ & - & - & - & - \\
\hline Smith et al., 2006 & Atlantic Canada & dairy & $\mathrm{SF}$ & Nov. 00-Mar. 02 & $15-17.5 \mathrm{~d}$ & $300 \mathrm{Ld}^{-1}$ & 99 & $94-96$ & $84-89$ & - & - & $90-98$ & - & - & - & - \\
\hline Thoren et al., 2004 & $\begin{array}{l}\text { Kalmar Dämme, } \\
\text { Sweden }\end{array}$ & dairy & SF & 1998-2001 & $<2-4 \mathrm{~d}$ & - & 52.2 & - & - & - & - & 50 & - & - & 17.9 & 32.8 \\
\hline $\begin{array}{l}\text { Tunçssiper } \\
\text { et al., } 2015\end{array}$ & Vermont, USA & dairy & SSF & Oct. 03-Jan. 06 & $3-60 \mathrm{~d}$ & - & $78-86$ & $67-94$ & - & - & - & - & - & - & - & - \\
\hline Vymazal et al., 2018 & Czech Republic & drainage, runoff & SF, SSF & 2014-2016 & - & - & 42 & 67 & 40 & - & 40 & - & - & - & 45 & 38 \\
\hline Wang et al., 2012 & Shanghai, China & dairy & SSF & $4 \mathrm{mo}$ & $6.5 \mathrm{~d}$ & $0.012 \mathrm{~m}^{3} \mathrm{~d}^{-1}$ & - & - & 91 & - & 87 & 88 & - & - & - & 80 \\
\hline Zhang et al., 2017 & Hokkaido, Japan & dairy, piggery & hybrid & 2006-2014 & - & - & 94-98 & $84-97$ & $71-90$ & - & $91-96$ & $40-85$ & - & - & - & $70-86$ \\
\hline Zhu et al., 2012 & Nanjing, China & dairy & hybrid & $180 \mathrm{~d}$ & $3 \mathrm{~d}$ & $0.125 \mathrm{~m}^{3} \mathrm{~m}^{-2} \mathrm{~d}^{-1}$ & & 86.5 & 80 & - & - & - & - & - & 95 & - \\
\hline
\end{tabular}

Note. ${ }^{*} \mathrm{P} 1$ : primary treatment pond; $* * \mathrm{~W}$ : free-water surface constructed wetland.

Agricultural wastewater can come in various forms depending on the agricultural activity taking place (Table 1), the composition and amount of wastewater produced may change throughout the year. During the winter months, a reduced volume of surface runoff is expected to be produced compared to the volume produced during the spring melt. Agricultural wastewater needs proper treatment to address pollution, prevent contamination of water sources, and manage contaminated waste (Harrington \& McInnes, 2009). Traditional methods of treating agricultural wastewater include the use of lagoon retention and spreading manure on the available fields (Harrington \& McInnes, 2009). In some cases, this process causes degradation to the surrounding water sources 
(Dunne et al., 2005). Poorly managed agricultural wastewaters have the potential to enter nearby surface waters from non-point sources associated with surface runoff, and from point-sources generally associated with concentrated farming activities, such as the production of livestock (Knight et al., 2000). A major concern for the freshwater systems that receive input from agricultural sources is often eutrophication; this is when there is an excessive amount of nutrients in the surface and groundwater, usually phosphates and nitrate- $\mathrm{N}^{-}\left(\mathrm{NO}_{3}{ }^{-} \mathrm{-}\right)$ (Gottschall et al., 2007). Constructed wetlands are an attractive alternative to treating high $\mathrm{NO}_{3}{ }^{-} \mathrm{N}$ waters. High $\mathrm{NO}_{3}{ }^{-} \mathrm{N}$ waters can be a major factor in the eutrophication of a waterbody and can pose a direct human health risk.

For many years, CWs have been used to treat municipal wastewater, but are now commonly used for agricultural applications (Table 1). Constructed wetlands are a method of managing the various types of wastewater produced on agricultural operations in a way that can be designed to meet the needs of both the producer and the environment. In achieving this, the wetland will help manage the farm effluents, increase habitat and biodiversity, and enhance the landscape. Additionally, CWs in agriculture areas can aid in the management of runoff and flooding. These systems are suitable to treat a variety of wastewaters around the farm, reducing nutrients, organic matter, solids, and pathogens within the wastewaters. The amount of waste is dependent on the farm management practices (Cronk, 1996). For example, in a dairy operation, typically a flush occurs after each milking. Milk is the major organic contaminant from the dairy parlour. Some of the milk is transferred through the pipeline into the waste stream. Other contaminants from the milkhouse could be manure and feed, detergent, acid wash, and possible water softener salts containing sodium and chloride. In cattle operations, runoff from livestock yard and manure piles may also need to be treated. This type of wastewater can be difficult to manage as it can have high nutrient values and is weather event driven, if not covered, leading to a pulse flow style loading into the wetland (Mejia-Franco et al., 2020). The development of the wetland should be implemented in a way that is practical, efficient and cost effective for the operator.

\subsection{Wetland Type}

Constructed wetlands are divided into two major groups based on hydraulic water flow characteristics in the system; surface flow (SF) and subsurface flow (SSF). Surface flow systems usually have a water depth of 0.2-0.6 $\mathrm{m}$ and are typically densely vegetated. The wastewater initially travels over the support medium, through plant stems, and through any surface debris. Sunlight passes into the bottom through a thin water basin within the system enabling a quicker algal growth rate, as well as active photodecomposition reactions. Surface flow systems can offer a lower construction cost compared to a SSF system, although SF wetlands usually have lower removal efficiency rates (Lee et al., 2009).

Like SF systems, SSF wetlands are usually constructed for the removal of various contaminants such as; biological oxygen demand (BOD), chemical oxygen demand (COD), suspended solids (SS), metals, nitrogen (N), and phosphorus (P) as well as pathogens. However, these types of wetlands are generally sealed by an impermeable substance to block any leakage, as well as media on the bottom of the wetland to aid in the growth of vegetation. Subsurface flow systems are subdivided into horizontal (HF) and vertical flow (VF) systems depending on the flow direction of the wastewater. Horizontal flow SSF wetlands do not have the capability for providing nitrification due to their limited oxygen $\left(\mathrm{O}_{2}\right)$ capacity, however in a VF SSF CW, they have optimal conditions for nitrification to take place. Denitrification does not occur in the VF systems. Nitrogen (N) removal can be limited due to the lack of $\mathrm{O}_{2}$ in the filtration bed, indirectly causing low nitrification to occur. Between VF and HF wetland systems, HF SSF are most used (Lee et al., 2009; Vymazal, 2017).

In some SSF wetlands, the use of both VF and HF systems are combined making a hybrid system. In these hybrid systems, the advantages of the HF and the VF can be combined to compliment processes in both systems to produce an effluent that is low in BOD, as well as fully nitrified and partly denitrified, which will have much lower total-nitrogen (TN) outflow levels. Multiple studies have shown that these hybrid systems can be used to increase treatment performance, mainly in the case of $\mathrm{N}$ removal (Lee et al., 2009; Vymazal, 2017; Wang et al., 2017). Numerous wetlands can be combined to achieve high treatment efficiencies, more so with regards to N. In both SSF style CWs, P removal is limited from low sorption capacity of filtration materials such as gravel and crushed rock (Vymazal, 2005).

When looking at what type of $\mathrm{CW}$ best suits the specific environment, it is important to choose a CW that works for the type of wastewater that is being treated, the available land, and the level of maintenance that will be provided for the system. For example, free water SF systems have been proven to be more effective when working with the treatment of animal wastewater (Hunt \& Poach, 2001), as these systems can handle high SS content and nutrient loadings. This system type has less operational demands and greater capacities for more 
extensive treatment, specifically for the removal and retention of P (Harrington \& McInnes, 2009). However, SF wetlands have been found to emit more greenhouse gases than SSF wetlands (Liu et al., 2009).

\subsection{Wetland Treatment Processes}

Constructed wetlands can be used as a secondary treatment to decrease the $\mathrm{O}_{2}$ demand in agricultural wastewater, or as a tertiary treatment to further remove BOD, solids, and nutrients by utilizing physical, biological, and chemical processes (Boyd et al., 2005; Fitch, 2014). A primary treatment is necessary to remove large solids (Fitch, 2014) to prevent clogging and short circuiting of the system. Constructed wetlands use a combination of aerobic shallow zones and anaerobic deep zones to remove ammonia $\left(\mathrm{NH}_{3}\right)$ in agriculture wastewater (Boyd et al., 2005). During the nitrification process, nitrifying bacteria will oxidize ammonium $\left(\mathrm{NH}_{4}{ }^{+}\right)$to nitrate $\left(\mathrm{NO}_{3}{ }^{-}\right)$in aerobic zones (Choudhary et al., 2011). This process occurs in 2 steps; Nitrosomonas bacteria converts $\mathrm{NH}_{4}^{+}$to nitrite $\left(\mathrm{NO}_{2}{ }^{-}\right.$), and Nitrobacter bacteria converts $\mathrm{NO}_{2}^{-}$to $\mathrm{NO}_{3}^{-}$(Choudhary et al., 2011). Denitrification occurs when organisms reduce $\mathrm{NO}_{3}{ }^{-}$to $\mathrm{N}_{2} \mathrm{O}$, which is further reduce to atmospheric nitrogen in anaerobic zones (Choudhary et al., 2011). The volatilization process allows aqueous $\mathrm{NH}_{3}$ to volatize to $\mathrm{NH}_{3}$ gas and be released into the atmosphere (Choudhary et al., 2011). These wetland mechanisms work together to remove $\mathrm{NH}_{3}$ from agriculture wastewaters. The physical solid waste removal mechanism in wetlands systems works by using filtration and settling (Boyd et al., 2005). Wetland filtration mechanisms removes contaminants such as SS, metals and pathogens in agriculture wastewater (Choudhary et al., 2011). The sedimentation process is a physical process where the larger particles precipitate out of the water column and settle on the wetland's sediment layer. This can be accomplished is by reducing the velocity of the water (O'Geen et al., 2010) and with the presence of emergent plants (Braskerud, 2002; Anderson \& Mitsch, 2006). This process reduces the turbidity and SS in the wastewater by retaining the contaminants in the wetland sediment (Johnston, 1991). To decrease the BOD in wastewater, microbes consume organics as they are capable of degrading most organic pollutants (Choudhary et al., 2011). Phosphorus removal in wetlands occurs through adsorption to sediment materials and soil (Johnston, 1991; Boyd et al., 2005; Harada et al., 2015; Rozema et al., 2016).

Constructed wetland mechanisms can be impacted by the low temperatures experienced in cold climates. Dormant vegetation and slow reactions times for soil and microbes during the winter months may affect wetland performance by decreasing both physical and biological activity (Werker et al., 2002). During the winter, the growth of vegetation is slowed, and $\mathrm{O}_{2}$ transfer is limited. Limited $\mathrm{O}_{2}$ transfer is unfavorable to the nitrification process in wetlands as there may not be enough dissolved oxygen (DO) present to meet the needs for the nitrifying process (Werker et al., 2002). A study by Wu et al. (2011) found that low DO concentration created anaerobic conditions that limit nitrification in cold temperatures (Wu et al., 2011). Nitrification has been found to be inhibited once temperatures reach $6^{\circ} \mathrm{C}$ and water temperatures reach $10^{\circ} \mathrm{C}$ (Werker et al., 2002). In terms of microbial activity in cold temperatures, bacteria growth and metabolic rates have been found to decrease (Faulwetter et al., 2009; Wu et al., 2011). Although, soil microbes still can decompose organic contaminants during the winter due to increased DO saturation concentrations as temperatures decrease from 20 to $0^{\circ} \mathrm{C}$ (Werker et al., 2002). The sedimentation process in CWs is weakly temperature dependent (Kadlec \& Reddy, 2001; Rozema et al., 2016). Higher sedimentation rates have been observed at higher temperatures, although sedimentation can persist in cold climate temperatures (Kadlec \& Reddy, 2001; Rozema et al., 2016).

\section{Operational Challenges and Considerations}

\subsection{Ice Formation}

Climatic conditions can be referred to as the biggest challenge when operating on-farm CWs year-round. In temperate climates, temperatures can drop below $0^{\circ} \mathrm{C}$ which can cause ice to form in the system. It is important to prevent ice formation, as well as ensure ice blockages do not occur throughout the system (Smith et al., 2005a). Ice blockages can create preferential flow pathways and short-circuiting (Smith et al., 2006), thereby reducing overall treatment efficiencies. Tracer studies during the winter months have been found to be useful in determining a wetland's RT and preferential flow paths (Smith et al., 2005a). Koskiaho et al. (2003) investigated three wetlands under boreal conditions in Finland and determined that the wetland with the longest RT had the best performance at retaining $\mathrm{TN}$ and total phosphorous (TP) in all seasons. In contrast, the $\mathrm{CW}$ with the shortest RT was occasionally a source for dissolved reactive $\mathrm{P}$ and $\mathrm{NO}_{3}{ }^{-} \mathrm{N}$ (Koskiaho et al., 2003). It is therefore important to determine the RT of the wetland system and alter it appropriately so that proper treatment can be achieved. Authors have suggested that the $\mathrm{CW}$ design can be adapted to colder seasons to improve overall treatment capacity by reducing mass loading rates and having longer RTs (Jenssen \& Mander, 2002; Werker et al., 2002; Smith et al., 2005a; Ouellet-Plamondon et al., 2006; Akratos et al., 2008). Others have suggested that 
seasonal effects are also related to factors such as influent quality, wetland design, plant species, primary treatment and feeding pattern (Kotti et al., 2010; Pedescoll et al., 2011; Taylor et al., 2011).

Aeration within a wetland has been shown to prevent total ice accumulation (Munoz et al., 2006; Chazarenc et al., 2009). Aeration has been found to increase DO availability, a limitation for wetland systems, and help to subsequently eliminate short-circuiting and clogging (Munoz et al., 2006). Aeration may also prevent freezing by promoting mixing in the water column and keeping the water at a warmer temperature (Munoz et al., 2006). Ouellet-Plamondon et al. (2006) found that artificial aeration improved both organic matter and $\mathrm{N}$ removal, especially in the winter; they believed this was due to stimulated heterotrophic bacterial activity without reducing denitrification. They also determined that total suspended solids (TSS) removal was also slightly enhanced in both winter and summer due to the physical action from the aeration system. Munoz et al. (2006) determined that an aeration system enhanced treatment capacity when treating feedlot runoff and milkhouse wastewater from a dairy farm. The aeration system was also found to increase both temperature and mixing in four SSF wetlands. These results remained consistent when later studies continued the work on these wetlands (Tunçsiper et al., 2015). Artificial aeration has been proven to be an effective methodology in improving treatment efficiencies, though does not compensate for the absence of plants in the wetland system (Ouellet-Plamondon et al., 2006; Wang et al., 2017).

The formation of ice and the subsequent melting of ice in cold climate wetlands can greatly impact the production of greenhouse gas (GHG) emissions. As the temperature decreases during the freezing period, carbon dioxide $\left(\mathrm{CO}_{2}\right)$ and methane $\left(\mathrm{CH}_{4}\right)$ emissions decrease with temperature (Wang et al., 2013). Short emission peaks of $\mathrm{CO}_{2}$ and $\mathrm{CH}_{4}$ were observed at the beginning of the freezing period, possibly because water soluble $\mathrm{CO}_{2}$ and $\mathrm{CH}_{4}$ were forced out of the growing ice structure (Teepe et al., 2001; Wang et al., 2013). The nitrous oxide $\left(\mathrm{N}_{2} \mathrm{O}\right)$ uptake capacity decreased during the freezing period, and the soil column became a sink for $\mathrm{N}_{2} \mathrm{O}$ (Wang et al., 2013). Microbial activity significantly decreased but continued to produce $\mathrm{CO}_{2}$ and $\mathrm{CH}_{4}$ during the frozen period, and the emissions were released through frost-induced cracks (Teepe et al., 2001). During the period of thaw, $\mathrm{CO}_{2}$ and $\mathrm{CH}_{4}$ emissions significantly increased, and emissions were positively correlated with soil temperature (Koponen \& Martikainen, 2004; Miao et al., 2012). Nitrous oxide emissions also increased with temperature, and the soil column sink was converted to a source (Wang et al., 2013).

\subsection{Treatment Performance in Low Temperatures}

In addition to the challenges of ice formation, low temperatures experienced in cold climate regions can also negatively impact wetland performance. Wetland performance is evaluated by the $\mathrm{N}$ removal rates, as this is predominantly controlled by soil microbes that can slow or stop functioning in low temperatures. Steinmann et al. (2003) identified a decrease in $\mathrm{NH}_{4}{ }^{+}-\mathrm{N}$ removal during the winter period compared to the summer period in a $\mathrm{HF}$ SSF CW in Morlbach, Germany. Similar to these findings, numerous studies have documented a temperature dependence with $\mathrm{NH}_{4}{ }^{+} \mathrm{N}$ (Akratos \& Tsihrintzis, 2007; Llorens et al., 2009; Garfi et al., 2012; Huang et al., 2013). For example, Garfi et al. (2012) found a negative removal efficiency in winter, indicating an increase in $\mathrm{NH}_{4}{ }^{-} \mathrm{N}$ from influent to effluent in the HF SSF wetlands that were examined. When comparing a Barcelona wetland operating in the winter months to the year-round operation of a Leon wetland, this study found higher mass removals in the Barcelona wetland (Garfi et al., 2012). They attributed these results to higher temperatures in Barcelona, suggesting that mass removal rates may be season dependent (Garfi et al., 2012). A study conducted by Gottschall et al. (2007) in Ontario, Canada examined the effects of climate on the removal of nutrients in an agriculture CW. Nutrient content changes throughout the year were consistent with the expected patterns for perennials where there is a maximum in above-ground tissues halfway through the growing season, followed by translocation to below ground tissues at the end of the season (Gottschall et al., 2007). Nitrogen removal is highly dependent on microbial activity in root zones and has been proven to be temperature sensitive (Gottschall et al., 2007).

Low temperatures can also impact other processes that do not rely as heavily on microbial activities. Several authors have reported that TSS removal has no seasonal difference (Ouellet-Plamondon et al., 2006; Llorens et al., 2009; Hijiosa-Valsero et al., 2010). This observation is expected since TSS removal is a physical process through sedimentation and filtration (Garfi et al., 2012). However, Garfi et al. (2012) found TSS to have a seasonal effect and attributed this to increased RT caused by increased water loss in the warm season. Low temperatures can affect the sedimentation function of the wetlands if they are receiving water while in a frozen state (Bosak et al., 2016). This occurrence is due to washwater freezing in layers over top of the already frozen layers (Bosak et al., 2016). This study use sedimentation as a pre-treatment, though ultimately presumes that freezing in cold climate environments will negatively impact biological treatment and sedimentation (Bosak et al., 2016). 
Numerous studies have shown that low temperatures impact $\mathrm{N}$ removal rates, therefore researchers have identified methodologies that can increase $\mathrm{N}$ removal during the low temperature periods. By using an Antarctic moss (Bryum muehlenbeckii) as a substrate material, Wang et al. (2012) found that the removal of $\mathrm{NH}_{4}{ }^{+}-\mathrm{N}$ was maintained in colder temperatures with a range of $5-20^{\circ} \mathrm{C}$. It performed better at the lower temperature ranges than the control mosses from the local area. It is suspected that the soil microbes associated with the moss were responsible for improving $\mathrm{N}$ removal in colder conditions (Wang et al., 2012). There are other methods to increase treatment efficiency and removal rates in wetlands, including the utilization of macrophytes, aeration, and heat protective layers, which will be further discussed in the following sections.

Despite numerous studies with opposing conclusions, several studies have found that low temperatures have no effect on $\mathrm{NH}_{4}{ }^{+} \mathrm{N}$ removal rates. A study by Mæhlum and Jenssen (2003) reported that there were no significant differences in $\mathrm{NH}_{4}{ }^{+}-\mathrm{N}$ removal between cold $\left(<4^{\circ} \mathrm{C}\right)$ and warm $\left(>11^{\circ} \mathrm{C}\right)$ periods. During a study period in Italy, three CWs treating milkhouse washwater found that low temperatures have little influence on the wetland system removal efficacy of the measured parameters (TSS, $\mathrm{BOD}_{5}, \mathrm{COD}, \mathrm{TP}, \mathrm{TN}$, total organic carbon). This was seen with the consistent removal rate of $80 \%$ for TSS over the course of the study and with the highest removal rate of $80 \%$ for COD corresponding to the coldest sampling date. The study noted that system failures were not due to low temperatures, but lack of regular maintenance to the wetland operation (Comino et al., 2011). This lack of maintenance led to electrical issues with the pump controls and clogging issues in the wetlands (Comino et al., 2011).

\subsection{Vegetation}

Vegetation plays an important role in wetland environments and has been known to enhance wetland treatment efficiency (Zhu et al., 2012). Macrophytes are crucial in stabilizing the surface of the beds, providing good conditions for filtration, preventing CW systems from clogging, insulating during the winter, and providing an area for microbial growth (Brix, 1997). Petticrew and Kalff (1992) found that vegetation not only takes up nutrients, but emergent plants also reduce flow velocity near the wetland bottom and increases the sedimentation of suspended particles.

The presence of vegetation can increase the removal efficiency of nutrients in a wetland. In cold climate wetlands, the main factor responsible for $\mathrm{N}$ removal is $\mathrm{N}$ assimilation by macrophytes (Choudhury et al., 2019). In southern Taiwan a study by Jing and Lin (2004) compared the removal efficiencies of non-vegetated and vegetated CWs and determined that the volumetric removal rate constant at $20^{\circ} \mathrm{C}\left(k v_{20}\right)$ was higher in vegetated wetlands $(0.321$, 0.208 , and $\left.0.252 \mathrm{~d}^{-1}\right)$ than in the control wetland $\left(0.034 \mathrm{~d}^{-1}\right)$. Due to the decreased $k v_{20}$ value in the control wetland, these results determined that macrophytes enhance $\mathrm{NH}_{3}-\mathrm{N}$ removal (Jing \& Lin, 2004). Ouellet-Plamondon et al. (2006) found similar results when testing with a greenhouse wetland in Montreal, QC with higher removal rates in planted units vs. unplanted units. In the summer months, Ouellet-Plamondon et al. (2006) found that the TKN removal efficiency in an unplanted wetland was $89.1 \%$, whereas the planted wetlands were found to have TKN removal efficiencies of $98.7 \%$ (reed) and $98.5 \%$ (cattail). This study also determined that the $\mathrm{NH}_{4}{ }^{+}-\mathrm{N}$ removal efficiency for the unplanted wetland was $42.9 \%$, compared to planted wetlands with $\mathrm{NH}_{4}{ }^{+}-\mathrm{N}$ removal efficiencies of $94.2 \%$ (reed and cattail). Similar results were found in the winter months; the TKN removal efficiencies of unplanted wetlands was $87 \%$ compared to planted wetlands with TKN removal efficiencies of $94.2 \%$ (reed) and 94.7\% (cattail). Ammonium-N $\left(\mathrm{NH}_{4}{ }^{+}-\mathrm{N}\right)$ removal efficiency for the unplanted wetland in the winter was minus $170.6 \%$, whereas planted wetlands had $\mathrm{NH}_{4}{ }^{+}-\mathrm{N}$ removal efficiencies of $64.7 \%$ (reed) and $88.2 \%$ (cattail). Cold temperatures did not influence this experiment; however, the temperatures were maintained at $5^{\circ} \mathrm{C}$ in the winter due to greenhouse conditions. Research conducted by Choudhury et al. (2019) highlights the importance of denitrification activity associated with macrophyte roots in cold-climate CWs and determined that macrophytes were effective at removing $\mathrm{N}$ using denitrification (Choudhury et al., 2019). Varying macrophyte species have differing $\mathrm{N}$ removal abilities, and the success of the $\mathrm{CW}$ is dependent on the correct choice of macrophyte species (Choudhury et al., 2019).

Vegetation is primarily beneficial during the growing season for the purpose of nutrient removal. Die-back during cold periods however, cause nutrients to be released back into the water, therefore creating a nutrient source and the potential to spike outlet concentrations. A study by Bosak et al. (2016) found that the winter breakdown of plant material can increase TSS in the system. Wei et al. (2020) conducted an experiment to see how the decomposition of emergent plants occurs under ice cover. In this study, it was found that the DO levels in the water dropped under the ice cover and remained low while the ice was present. It was also found that there was a rapid increase in $\mathrm{N}, \mathrm{P}$ and $\mathrm{C}$ but it tapered off as the experiment continued. There was rapid mass loss of vegetation during the initial stages, and the loss slowed as the experiment progressed. This contributed to the loss of small dissolvable parts of the plant material (Wei et al., 2020). It is predicted that freeze thaw fluctuations 
could cause similar effects, as the movement and reformation of the ice layer could aid with the mechanical breakdown of the plant material in the ice layer. The decomposition of plant material and freeze thawing cycling can also lead to higher TN levels being exported, as was seen in wetlands in Sweden (Thorén et al., 2004). Thorén et al. (2004) found when the HLR increased during a freshet, the amount of TN exported from the wetland increased $186.1 \%$ compared to the $3 \mathrm{yr}$ average. This melt also caused the wetland to become a source for N, with the concentration increasing from 7.5 at the inlet to $8.0 \mathrm{mg} \mathrm{L}^{-1}$ at the outlet (Thorén et al., 2004). Newman et al. (1999) showed a comparison between three different species of vegetation (narrow-leaved cattail Typha angustifolia L., common reed Phragmites australis Cav., and three-square bulrush Scirpus pungens Vahl.) used in a cold climate SF CW in Connecticut, USA. There was a noticeable change in vegetation dominance a year after planting, the T. angustifolia and P. australis cells were dominated by the original rootstock vegetation. In 1994, the $T$. angustifolia wetland cell had the greatest plant biomass and the $P$. australis cell had the least plant biomass.

Some studies have recommended that harvesting vegetation helps better manage long-term nutrient loss (Vymazal \& Dvorakova, 2018) to mitigate the impact vegetation can have during the winter months. This harvesting may also lead to an increase in biomass from certain wetland species when the above structure is harvested twice in a growing season (Vymazal \& Dvorakova, 2018). The study conducted by Wang et al. (2015) indicated that the timing of harvesting is also important to consider. This study found that harvesting the plants before the temperature decreased below $4^{\circ} \mathrm{C}$ would decrease the level of $\mathrm{O}_{2}$ released by the roots. This decrease in released $\mathrm{O}_{2}$ would affect the microbes that are in the rhizosphere (Wang et al., 2015). The difference in the $\mathrm{O}_{2}$ released had less distinction between the harvested and non-harvested treatments in this study when the temperature was below $4^{\circ} \mathrm{C}$ (Wang et al., 2015).

If vegetation is left unharvested, it can act as an important insulating agent or thermal barrier against ice formation in the colder temperatures (Munoz et al., 2006; Smith et al., 2006; Vymazal \& Březinová, 2014). Vymazal and Březinová (2014) found that having a dense above ground biomass that remains unharvested in the fall is great at preventing freezing aboveground. Four HF SSF systems located in mountainous and sub-mountainous areas of the Czech Republic indicated no significant differences between summer (May-Oct.) and winter (Nov.-Apr.) months for the treatment of $\mathrm{NH}_{4}{ }^{+}-\mathrm{N}$ by the wetlands. Kadlec and Reddy (2001) and Allen et al. (2002) reported that vegetation can contribute to an overall reduction in organic materials, in turn contributing to a more effective hydraulic performance of a system. In Southern Finland, mean temperatures ranged from $-7^{\circ} \mathrm{C}$ in January to $10^{\circ} \mathrm{C}$ in July (Koskiaho et al., 2003). In this case, vegetation was considered to play a key role for proper functioning in winter conditions. Flow velocity had been found to be reduced in the wetland with an increase of sedimentation of suspended clay particles from the presence of macrophytes. In other words, CWs appear to function primarily as sedimentation basins by decreasing flow velocity (Koskiaho et al., 2003).

If vegetation is left undisturbed in the wetland, it can also aid in making the wetland a carbon (C) sink. Storing $\mathrm{C}$ in the sediment of a wetland is the main way these systems can sequester $\mathrm{C}$. The $\mathrm{C}$ that is stored in sediment is mainly in the form of organic $\mathrm{C}$ from the vegetation that is grown in their locations (Bernal \& Mitsch, 2012). In systems where the sediment can be retained for a long time, such as wetlands, the $\mathrm{C}$ sequestration can be 2.5 times higher than flow through systems such as rivers (Bernal \& Mitsch, 2012). This difference was observed by Mitsch et al. (2014) when comparing the $\mathrm{C}$ sequestration rate of two river side CWs to a naturally formed wetland that are better designed to promote sedimentation. There are additional parameters to examine when considering if vegetation will help a wetland be a $\mathrm{C}$ sink or a source. When a new SF wetland is formed and the area is flooded, the soil becomes submerged and new plants start to grow in the area. These conditions can favour bacteria and other microbiota that can be $\mathrm{CH}_{4}$ producers. This new source of $\mathrm{CH}_{4}$ production does need to be factored in when considering if a wetland will be a source or sink for GHGs. The Badiou et al. (2011) study found that even when the increase in $\mathrm{CH}_{4}$ emission was accounted for, approximately $3.25 \mathrm{Mg} \mathrm{CO}_{2}$ equivalents per ha per yr could be sequestered in the restored wetlands. Though, there are several factors than can reduced the level of $\mathrm{CH}_{4}$, including electron acceptors such as sulphate and emergent vegetation. As the presence of sulphate increases in some systems, the production of $\mathrm{CH}_{4}$ will decrease (Pennock et al., 2010). However, this relationship tends to plateau at a reduction of approximately $60 \%$ of $\mathrm{CH}_{4}$ emissions (Linquist et al., 2012). The presence of varying vascular plant species can impact $\mathrm{CW} \mathrm{CH}_{4}$ emissions, and these plants are an important factor for determining $\mathrm{CH}_{4}$ fluxes (Joabsson et al., 1999). In some wetlands the level of $\mathrm{CH}_{4}$ released can be higher in the open water sections of the wetland compared to the vegetated sections (Pennock et al., 2010). When this vegetation dies off it can lead to an increase in $\mathrm{CH}_{4}$ production, as the increase in organic $\mathrm{C}$ into low $\mathrm{O}_{2}$ conditions will favour methanogenesis (Kaushal et al., 2014). As vegetation dies off as a yearly occurrence in temperate climates, these impacts need to be taken into consideration. 
Another GHG that can be released by wetlands, aside from $\mathrm{CH}_{4}$, that is affected by the presence of vegetation is $\mathrm{N}_{2} \mathrm{O}$. The amount of $\mathrm{N}_{2} \mathrm{O}$ that can be released can vary greatly in wetlands. Wetlands receiving agricultural drainage wastewater can range from 0.2 to $3.8 \mathrm{mg} \mathrm{N} \mathrm{m}^{-2} \mathrm{~d}^{-1}$, where wetlands treating swine wastewater can be 1.3 to $749.8 \mathrm{mg} \mathrm{N} \mathrm{m}^{-2} \mathrm{~d}^{-1}$ (Zhang et al., 2019). The release of $\mathrm{N}_{2} \mathrm{O}$ in a wetland will fluctuate throughout the year depending on factors such as season and nutrient load entering the system (Zhang et al., 2019). In studies based in Canada's Prairie Pothole Region, the levels are usually very low to non-detectable with the release of $\mathrm{N}_{2} \mathrm{O}$ being higher in the open sections of a wetland (Pennock et al., 2010; Badiou et al., 2011). A way that plants aid with the reduction in $\mathrm{CH}_{4}$ and $\mathrm{N}_{2} \mathrm{O}$ production is by promoting aerobic conditions in their rhizosphere with respiration from their roots (Chen et al., 2020). With the increase of $\mathrm{O}_{2}$ to the system from the plants the amount of anaerobic digestion of plant matter will decrease. Since most $\mathrm{CH}_{4}$ producing bacteria favour anaerobic conditions, their presence will be reduced leading to a reduction in $\mathrm{CH}_{4}$ produced.

Although establishing plant communities in CWs can be beneficial, there are certain challenges that may arise. Challenges that can occur in northern climates include a shortened growing season, winter die off, and animals, such as muskrats, hindering the plant communities. Muskrats are almost completely dependent on wetland environments, and being as they are primary herbivores, they will consume the vegetation that is present in the wetland (Mortsch, 1998). This is problematic when muskrats are present in large numbers as they can consume enough vegetation for what is classed as an "eatout" (Kadlec et al., 2007). This may involve 100\% of the emergent plant material being eaten by the muskrat population (Kadlec et al., 2007). This loss of canopy can increase the amount of GHGs released to the atmosphere (Kaushal et al., 2014). Muskrats will also utilize deep-water pathways through vegetation to travel discretely throughout the wetland, and these pathways can cause a reduction in treatment efficiency (Kadlec et al., 2007). These pathways serve as channels that facilitate short-circuiting of water through the wetland (Kadlec et al., 2007). Even if there is not total vegetation lost, there can also be negative effects caused by muskrats eating the emergent plant material. They will open a section of wetland and expose open water, which will allow waterfowl to land on the wetland. This waterfowl can then eat the emerging shoots of plants preventing the regrowth in the cleared areas (Kadlec et al., 2007). However, if waterfowl are not a factor the opened spaces may promote increased species richness in the vegetation as competition is reduced (Bomske \& Ahlers, 2020). The impact of muskrats on CW treatment performance is understudied at this point in time (Kadlec et al., 2007). The range of muskrats covers much of the temperate regions of North America (Kadlec et al., 2007). Therefore, considerations must be taken to mitigate their effect on cold climate wetlands and prevent the damages that can be caused to the vegetation and flow paths needed for proper function.

\subsection{Heat Preservation Layer}

Having a barrier between the wetland surface and low air temperature can be very useful for operating a wetland during the winter months. There are various types of barriers depending on the design characteristics of the wetland and material available. In Atlantic Canada, Smith et al. (2006) found that by providing an insulating air gap between the frozen water on top of a SF wetland and the unfrozen water below, treatment efficiencies can be maintained and enhanced. This practice prevents total ice formation from occurring. A study by $\mathrm{Wu}$ et al. (2011) in China also observed no significant loss of treatment efficiencies during the winter when a surface layer of sawdust was present. The insulation was important not only in preventing freezing of the wetland, but also to ensure lower temperatures do not inhibit nitrification (Wu et al., 2011). Kadlec and Reddy (2001) observed snow and ice as a heat preservation cover; however, with complete cover there is a potential blockage of $\mathrm{O}_{2}$ transfer that could create an indirect shortfall of $\mathrm{O}_{2}$ within the system. Mæhlum and Jensson (2003) also found it was difficult to rely on snow and ice as a cover for a constructed wetland. The snow and ice layer would have to be constantly maintained to ensure there were no cracks, exposing the effluents which could result in considerable heat loss. It can be hard to maintain ice cover in many areas when temperatures constantly fluctuate.

The need for a heat preservation layer for operation in a cold climate can also be seen in SSF wetlands. The study conducted by Grebenshchykova et al. (2020) found that the addition of a snow layer was beneficial for operating a VF SSF wetland during the winter in southern Quebec. They maintained a 5-10 $\mathrm{cm}$ water level below the surface to prevent heat loss and allowed a snow layer to persist throughout the winter as an insulating layer (Grebenshchykova et al., 2020). A study by Gorra et al. (2014) found that a consistent snow cover during the winter months maintained a temperature close to $0^{\circ} \mathrm{C}$ of the substrata (Gorra et al., 2014). The snow cover had been shown to protect the soil by maintaining unfrozen conditions between 1 and $-3^{\circ} \mathrm{C}$, and therefore sustained high biological activity in temperatures approaching sub-zero (Gorra et al., 2014).

As opposed to using ice or snow as a barrier between the wetland and the atmosphere, other methods have been used. Huang et al. (2013) suggested that PVC film could be used to cover the surface of a wetland for heat 
preservation. This would allow for the wetland to be protected from sub $0^{\circ} \mathrm{C}$ temperatures. In northern Japan a porous layer made from recycled glass (Supersol) was used for a hybrid SSF system treating dairy washwater along with other wastes (Kato et al., 2013; Harada et al., 2015). Another method involved building a structure or greenhouse around the wetland for protection (Gao \& Hu, 2012). These greenhouses can then be used to help offset costs by growing exotic plants to later be sold (Gao \& $\mathrm{Hu}, 2012$ ).

\subsection{Design Challenges Under Cold Conditions}

The challenges faced in cold climate regions can differ depending on whether a SF or SSF system is present. Horizontal flow SSF CWs can be integrated into cold climate environments in order to treat wastewater (Ouellet-Plamondon et al., 2006), though there are certain benefits and limitations of these systems. In HF SSF CWs, water flows beneath the bed surface under the frost layer of the soil, reducing the chance of hydraulic failure from freezing (Ouellet-Plamondon et al., 2006). Many physical processes, including sedimentation and decantation, are resistant to winter conditions, therefore are not affected by freezing in cold climates (Ouellet-Plamondon et al., 2006). Although, certain biological processes are directly affected by winter conditions which can reduce the ability for SSF CWs to remove $\mathrm{N}$ and soluble organic matter during the winter months (Ouellet-Plamondon et al., 2006). A limiting factor of SSF systems is low available $\mathrm{O}_{2}$, which may be further increased in the winter freezing (Ouellet-Plamondon et al., 2006). Subsurface flow systems are also believed to be subjected to increased clogging and limited $\mathrm{O}_{2}$ diffusion when compared to free-water SF systems (Hunt \& Poach, 2001). To address this issue Kato et al. (2013) added bypass mechanisms that allowed wastewater to circumvent a clogged section and move to the next bed. Other studies have suggested that the use of pre-treatment is essential for operation for both SSF and SF systems (Smith et al., 2006; Rozema et al., 2016; Smith et al., 2019). Artificial aeration can increase DO levels in SSF CWs, resulting in decreased clogging and avoidance of potential preferential flow patterns by raising the wetlands temperature and mixing of effluent (Munoz et al., 2006). In terms of contaminant removal, SSF CW systems can remove a higher rate of contaminates per unit of land compared to SF CWs (Halverson, 2004). This means that SSF CW systems can be constructed at a smaller size while maintaining the same level of contaminate removal as larger SF systems (Halverson, 2004). Although SSF CWs can be smaller than SF CWs for the same level of contaminate removal, SSF CWs typically cost more per acre (Halverson, 2004).

In comparison, SF CWs are the most common type of treatment used for animal wastewater in the United States (Cronk, 1996). These systems are beneficial for wastewaters containing high suspended solids, such as agriculture waste, and can offer greater control of water flow (Halverson, 2004). As described by Carty et al. (2008) the treatment effectiveness of SF wetlands systems in comparison to SSF systems is typically based on having appropriate HRTs, which depend on the specific site conditions. Due to the exposed free water surface, SF CWs offer a more diverse habitat for wildlife and plant species (Halverson, 2004). Surface flow CWs offer low construction costs because of fewer construction steps and materials involved compared to SSF systems (Cronk, 1996; Lee et al., 2009). More land is also required to construct a SF CW to attain the level of removal of a SSF CW (Halverson, 2004). Construction and maintenance costs are lower for both SF CW and SSF CW systems compared to conventional wastewater treatments (Halverson, 2004).

Hybrid SSF systems have been found to be very effective for treating agriculture wastewater in a temperate climate. A study conducted by Sharma et al. (2013) found that removal rates of TSS and $\mathrm{BOD}_{5}$ remained consistent throughout the winter months (Sharma et al., 2013). The chemical oxygen demand by dichromate $\left(\mathrm{COD}_{\mathrm{Cr}}\right)$, TN and total $\mathrm{C}$ removal rates slightly varied, increasing by 3-4\% during the warm periods, although the slight increase in $\mathrm{COD}_{\mathrm{Cr}}$ could be attributed to a higher average load in the warm periods (Sharma et al., 2013). This study determined that hybrid SSF systems can reach purification and removal rates of $>95 \%$ for TSS, $>$ $95 \%$ for total coliform, $>89 \%$ for $\mathrm{COD}_{\mathrm{Cr}},>89 \%$ for $\mathrm{BOD}_{5},>76 \%$ for $\mathrm{TN}$, and $>72 \%$ for TP during both the cold and warm periods (Sharma et al., 2013). Sharma et al. (2013) determined that purification and removal efficiencies of hybrid SSF systems are consistent during both the warm and extremely cold periods, concluding that these systems are efficient at treating milk parlour waste. A study by Zhang et al. (2017) found similar results when analyzing three piggery and dairy wastewater hybrid SSF systems, where the total COD removal efficiency was 90\% (Zhang et al., 2017). The study also found a correlation between high TP loads and high removal rates, and overall determined hybrid SSF systems to be efficient at treating both piggery and milking parlour wastewater in cold conditions (Zhang et al., 2017).

In terms of agriculture application, SF CW systems and SSF CW systems vary for differing factors. In SF CWs, the average HLRs fall between 0.3 and 2 inches per day, corresponding with wetlands between 18.7 to 131 ac per million gallons per day of flow (Halverson, 2004). In SSF CWs, the average HLRs fall between 0.8 to 8 inches per day, corresponding with wetlands between 4.7 to 47 ac per million gallons per day of flow (Halverson, 
2004). Accumulated earth and plant debris creates an insulation effect on the unsaturated surface layer, making SSF CWs more adapted to cold climates than SF CW systems (Halverson, 2004; Wang et al., 2017). Although, SSF CWs are best used for wastewater with low solid concentrations in order to prevent clogging of the substrate (Halverson, 2004). The performance of both SF CWs and SSF CWs were improved from use of pre-treatment (Smith et al., 2006; Rozema et al., 2016; Smith et al., 2019). In SF CWs, a study by Bosak et al. (2016) determined that increasing the HRT resulted in an improved performance and eliminated winter loading (Bosak et al., 2016). Subsurface wetlands can be further improved by modifying the pre-treatment of the CW system in order to decrease the load in influent water (Mantovi et al., 2003). In terms of agricultural waste, SSF CW systems in Atlantic Canada treating dairy wastewater had removal efficiencies of $95 \%$ for TSS, $99 \%$ for $\mathrm{BOD}_{5}$, $94 \%$ for $\mathrm{NH}_{4}$, and $92 \%$ for TP (Wang et al., 2017). Subsurface flow systems in Nova Scotia, Canada treating dairy wastewater have removal efficiencies of $95.8 \%$ for COD, $95.2 \%$ for $\mathrm{NH}_{4}{ }^{+}$, and $69.6 \%$ for TP (Wang et al., 2017). Surface flow CW systems treating agricultural runoff in Kalmar Damme, Sweden have removal efficiencies of $52.2 \%$ for $\mathrm{BOD}_{5}, 50 \%$ for $\mathrm{NH}_{4}, 17.9 \%$ for $\mathrm{NO}_{3}$, and $32.8 \%$ for $\mathrm{TN}$ (Wang et al., 2017). Surface flow CWs are also an effective treatment for varying types of agriculture wastewater and runoff and are better suited for warm environments with a low DO content (Beutel et al., 2009). During the winter months, SSF CWs have decreased $\mathrm{N}$ removal and inhibited decontamination (Ji et al., 2020). However, SSF CW systems can maintain the removal efficiencies of TSS, organic matter, and P throughout cold climate periods (Ji et al., 2020).

\subsection{Wetland Depth}

Wetland depth has potential to fluctuate in temperate climates, and varying water depths have differing effects on $\mathrm{CW}$ function. Liu et al. (2016) found that as the water depth increased, the reaction rate decreased which slowed contaminate removal rate in the wetlands (Liu et al., 2016). Decreasing water depth during cold periods in a CW can allow the system to achieve an insulating effect and prevent ice formation (Smith et al., 2005a). These results suggested that controlling water depth in CWs may reduce negative impacts from cold climate periods. Hydraulic efficiency and surface area also decreased as the water depth increased (Liu et al., 2016). Optimal wetland performance is characterized by high hydraulic efficiency, concluded that lower wetland depth provided optimal wetland performance (Liu et al., 2016). Seasonal changes from winter to spring caused snow accumulation to melt resulting in higher water depth (Smith et al., 2005a). This transition period could result in decreased wetland removal efficiencies due to the elevated water depth in cold climate environments. Varying experimental and pilot scale studies conducted in Spain have repeatedly proven that shallower HF SSF CWs (water depth 0.2-0.5m) provided higher removal efficiency compared to conventional HF SSF CWs (water depth about $0.5-0.7 \mathrm{~m}$ ) (Garfi et al., 2012). Due to these results, wetlands in Spain were designed with a lower depth, and these systems were shown to have a higher removal efficiency than conventional SSF CWs (Garfi et al., 2012). In SF CWs improved efficiency was seen in wider wetlands compared to deeper wetlands (Ioannidou \& Pearson, 2018).

Wetland depth and varying water levels impact GHG emissions in CWs. The study by Mander et al. (2011) analyzed results from varying SSF wetland research, and the majority of the data determined that $\mathrm{CH}_{4}$ emissions decreased in pulsing water conditions. Although, there was experimental data that showed an increased $\mathrm{CH}_{4}$ flux when the water table fluctuated (Mitsch et al., 2009; Mander et al., 2011). Bubier et al. (1993) found that as the water table becomes lower, the $\mathrm{CH}_{4}$ flux will increase. Methane emissions vary depending on the water table, and a low static water level has a lower $\mathrm{CH}_{4}$ flux compared to a high static water level (Mander et al., 2011). The release of $\mathrm{CH}_{4}$ from wetlands can fluctuate greatly during a growing season from factors such as the water level increasing and decreasing. When examining $\mathrm{N}_{2} \mathrm{O}$ emissions, the results from varying research concluded that the $\mathrm{N}_{2} \mathrm{O}$ flux significantly increased in pulsing water conditions (Hernández \& Mitsch, 2006; Song et al., 2010; Mander et al., 2011). The production of $\mathrm{N}_{2} \mathrm{O}$ is heightened in wetlands when there is increased soil water content, available organic $\mathrm{C}$, and available mineral $\mathrm{N}$ (Freeman et al., 1997). When wetlands are experiencing a drought, $\mathrm{NO}_{3}{ }^{-}$availability decreased and caused a significant decline in $\mathrm{N}_{2} \mathrm{O}$ emissions (Freeman et al., 1997). These results suggested that $\mathrm{N}_{2} \mathrm{O}$ emissions are dependent on the frequency and length of the water level fluctuations (Mander et al., 2011). In wetlands, the water level can change greatly during the growing season. Temperate climate wetlands in Canada experience significant water level fluctuations in the freshet during the spring as the snowpack melts. Due to the significant temperature variations and freeze-thaw conditions in cold regions, wetland water level can drastically change throughout the year. This means that $\mathrm{CH}_{4}$ and $\mathrm{N}_{2} \mathrm{O}$ emissions would vary depending on the season, and the pulsing water conditions could result in increased emissions. As climate patterns in temperate regions continue to alter due to climate change, the effects on water depth will become more pronounced.

Wetlands in temperate regions can also experience dry climate periods and drying from climate change. Drying effects and decreasing water levels in wetlands can alter the soil moisture and groundwater, ultimately reducing 
wetland size or converting the wetlands to uplands (Klein et al., 2005). This could greatly impact treatment by altering the water levels and changing wetland soil conditions. Climate change is having a significant effect on water levels in temperate regions, and the changing climate will continue to negatively influence wetlands due to their vulnerability from hydrological changes (Klein et al., 2005). Cold climate environments can also experience temporary dry climate periods, which affects wetlands by drying out the benthic zones and exposing the soil (McCauley et al., 2015). The soil initiates nutrient cycling, resulting in increased wetland productivity when the wet conditions are restored (McCauley et al., 2015). A study by Chen et al. (2018) demonstrated that wetland drying influenced soil redox reactions, resulting in increased wetland soil $\mathrm{CO}_{2}$ emissions (Chen et al., 2018). This research also identified that wetland drying increased temperature sensitivity of decomposing soil organic C (Chen et al., 2018). Increased temperature and more variable precipitation patterns can lead to increased drawdown of water levels in wetlands (Salimi et al., 2021). To mitigate these factors, producers have to more actively manage SF CWs to ensure that the water levels stay at an optimal depth to reduce emissions.

\subsection{Long-Term vs. Short-Term}

Constructed wetlands are proven to be an effective short-term wastewater treatment method, and it is also important to consider their long-term performance. Results from a study in China with a SF CWs demonstrated that the system could effectively reduce the output of $\mathrm{SS}, \mathrm{BOD}_{5}, \mathrm{COD}$, total coliform, and fecal coliform over a long-term period (Song et al., 2006). The lifespan of a CW is affected by factors such as solids in the inflow, detritus accumulating on the sediment and the height of the embankments (Carty et al., 2008). Solid accumulation and material build-up can clog the wetland and reduce the overall lifespan (Tanner \& Sukias, 1995) but maintaining aerobic soil can help control the clogging process under various temperatures (De Vries, 1972). As the wetland matures, the microbial communities and vegetation become more established, therefore increasing the nutrient removal efficiencies. This creates a stable system with a high pollutant removal capacity (Mustafa et al., 2009). A study by Mustafa et al. (2009) determined that the nutrient removal efficiency of a wetland system remains high in the $6^{\text {th }}$ year of operation, with removal rates of $99.6 \%$ for $\mathrm{NH}_{4}{ }^{+}-\mathrm{N}, 86 \%$ for $\mathrm{NO}_{3}{ }^{-} \mathrm{N}$, and $93.2 \%$ for reactive $\mathrm{P}$ (Mustafa et al., 2009). This study also discovered that the withered plant biomass increased as the wetland ages, increasing the $\mathrm{P}$ storage capacity and converting the system to an organic base with increased P removal capacity (Mustafa et al., 2009). Research conducted by Vymazal and Březinová (2014) found comparable results; the removal efficiency of $\mathrm{NH}_{3}-\mathrm{N}$ improved over time, and the TP nutrient removal efficiency remained consistent over the 18 yr period of operation (Vymazal \& Březinová, 2014). This study found that there were no significant statistical differences between removal efficiencies of $\mathrm{BOD}_{5}$, TSS, and $\mathrm{NH}_{4}{ }^{+}-\mathrm{N}$ between the summer and winter months, concluding that SSF CWs are a reliable long-term treatment method (Vymazal \& Březinová, 2014). For wetlands to be an effective in temperate regions, it is best that these systems be designed and adapted to subfreezing temperatures. Smith et al. (2019) also found that CWs can be restored once their saturation point is reached and can also be adapted to the changing climate.

\section{Considerations for Year-Round Operation}

Multiple authors have suggested that more research on wetland management needs to be undertaken to ensure long-term successful operation, as all wastewater types and volumes are different. Not all wetlands should be treated the same; design and management however are key to ensuring adequate treatment. Future investigations are needed to evaluate the long-term treatment performance of cold climate wetland systems. Climate variability can create challenges and it is important to design a system based on the local climate. Constructed wetlands can be used to treat various wastewater types in temperate climates, as can be seen in many studies; however, precautions should be taken. This review has made note of the following key considerations that should be looked when trying to achieve adequate year-round treatment:

(i) Proper design: wetland water level should be considered; deeper wetlands have less freezing potential but do not always promote aerobic conditions without an aeration system present. Deeper area may also be used by animals such as muskrat and can lead to short circuiting of the flow paths. Measures such as fencing or gravel in the banks may be considered to make the wetland less attractive for muskrats to colonize.

(ii) The length to width ratios of a system should be considered to minimize short-circuiting and preferential flow paths.

(iii) On-site soil characteristics may require the use of a liner; the use of a poly-synthetic liner is a safety net for potential leaching. Liners can also reduce issues with seasonal variations. Precipitation events are sometimes referred to as the primary factor affecting design.

(iv) Adequate pre-treatment will help prolong operation and reduce management due to clogging. 
(v) Removal of wastewater parameters may vary throughout seasons due to weather patterns and variations in inflow. Regular water testing is important to understand how the system is working under all seasonal climatic conditions.

(vi) Placing the wetland in a sheltered/treed area can help to maintain warmer temperatures and snow drift for insulation purposes.

(vii) The presence of vegetation can help to also trap snow, which in turn can act as an insulating layer to retain heat for maintaining biological treatment processes.

(viii) Managing the water level before and after freezing is useful to obtain an insulating air gap between frozen and unfrozen water. This allows for biological processes to continue.

(ix) Wetlands do have a lifespan and regular water sampling will help to identify a wetland's saturation point. Wetlands will have to be rehabilitated after reaching that point.

(x) A useful decision support tree is provided in Carty et al. (2008) when considering wetland implementation for the purposes of farmyard treatment. This could also be suggested for other wastewater types.

(xi) An effective and efficient RT (in both high and low flow periods) must also be achieved, ensuring the proper wetland size and inflow will help determine what is needed.

(xii) Utilizing artificial aeration is also beneficial in SF and SSF wetlands by increasing DO, temperature, and mixing while preventing preferential flow patterns and clogging in the wetland system.

(xiii) Hybrid wetlands systems are beneficial for nitrification and denitrification processes and have the potential to have higher pollutant removal efficiencies compared to a SSF CW system.

(xiv) Utilizing a heat preservation layer can prevent freezing and maintain high biological activity during colder periods.

Wastewater is a year-round issue for many farms, and because of this, year-round solutions are needed for proper treatment. Constructed wetlands are being promoted by extension specialists and environmental farm planners for treatment in warm seasons, and these systems are helping producers meet new environmental requirements. As the research reviewed in this paper shows CWs can also be an effective means of on-farm wastewater treatment in temperate climates when managed properly. This will involve taking into consideration the unique challenges that are present in a temperate climate. With continued research in this field, efficiency can be improved, and the adoption rate by producers can be increased as they see higher treatment efficiencies for their individual treatment needs, and climatic conditions.

\section{Acknowledgements}

This research was funded by Agriculture and Agri-Food Canada and Dalhousie University, Faculty of Agriculture.

\section{References}

Akratos, C. S., \& Tsihrintzis, V. A. (2007). Effect of temperature, HRT, vegetation and porous media on removal efficiency of pilot-scale horizontal subsurface flow constructed wetlands. Ecological Engineering, 29(2), 173-191. https://doi.org/10.1016/j.ecoleng.2006.06.013

Akratos, C. S., Papaspyros, J. N. E., \& Tsihrintzis, V. A. (2008). An artificial neural network model and design equations for BOD and COD removal prediction in horizontal subsurface flow constructed wetlands. Chemical Engineering Journal, 143(1-3), 96-110. https://doi.org/10.1016/j.cej.2007.12.029

Allen, W. C., Hook, P. B., Biederman, J. A., \& Stein, O. R. (2002). Temperature and wetland plant species effects on wastewater treatment and root zone oxidation. Journal of Environmental Quality, 31(3), 1010-1016. https://doi.org/10.2134/jeq2002.1010

Anderson, C. J., \& Mitsch, W. J. (2006). Sediment, carbon, and nutrient accumulation at two 10-year-old created riverine marshes. Wetlands, 26(3), 779-792. https://doi.org/10.1672/0277-5212(2006)26[779:Scanaa]2.0. $\mathrm{Co} ; 2$

Avsar, Y., Tarabeah, H., Kimchie, S., \& Ozturk, I. (2007). Rehabilitation by constructed wetlands of available wastewater treatment plant in Sakhnin. Ecological Engineering, 29(1), 27-32. https://doi.org/10.1016/ j.ecoleng.2006.07.008 
Badiou, P., McDougal, R., Pennock, D., \& Clark, B. (2011). Greenhouse gas emissions and carbon sequestration potential in restored wetlands of the Canadian prairie pothole region. Wetlands Ecology and Management, 19(3), 237-256. https://doi.org/10.1007/s11273-011-9214-6

Bernal, B., \& Mitsch, W. J. (2012). Comparing carbon sequestration in temperate freshwater wetland communities. Global Change Biology, 18(5), 1636-1647. https://doi.org/10.1111/j.1365-2486.2011.02619.x

Beutel, M. W., Newton, C. D., Brouillard, E. S., \& Watts, R. J. (2009). Nitrate removal in surface-flow constructed wetlands treating dilute agricultural runoff in the lower Yakima Basin, Washington. Ecological Engineering, 35(10), 1538-1546. https://doi.org/10.1016/j.ecoleng.2009.07.005

Bomske, C. M., \& Ahlers, A. A. (2020). How do muskrats Ondatra zibethicus affect ecosystems? A review of evidence. Mammal Review, 51(1), 40-50. https://doi.org/10.1111/mam.12218

Bosak, V., VanderZaag, A., Crolla, A., Kinsley, C., \& Gordon, R. (2016). Performance of a Constructed Wetland and Pretreatment System Receiving Potato Farm Wash Water. Water, 8(5). https://doi.org/ $10.3390 /$ w8050183

Boyd, N., Gordon, R., Cochrane, L., Jamieson, R., Dehaan, R., \& Glass, V. (2005). Constructed Wetlands for the Treatment of Agricultural Wastewater in Atlantic Canada. Atlantic Committee on Land And Engineering.

Braskerud, B. C. (2002). Factors affecting nitrogen retention in small constructed wetlands treating agricultural non-point source pollution. Ecological Engineering, 18(3), 351-370. https://doi.org/10.1016/s0925-8574 (01)00099-4

Brix, H. (1997). Do macrophytes play a role in constructed treatment wetlands? Water Science and Technology, 35(5), 11-17. https://doi.org/10.1016/s0273-1223(97)00047-4

Bubier, J. L., Moore, T. R., \& Roulet, N. T. (1993). Methane Emissions from Wetlands in the Midboreal Region of Northern Ontario, Canada. Ecology, 74(8), 2240-2254. https://doi.org/10.2307/1939577

Carty, A., Scholz, M., Heal, K., Gouriveau, F., \& Mustafa, A. (2008). The universal design, operation and maintenance guidelines for farm constructed wetlands $(\mathrm{FCW})$ in temperate climates. Bioresource Technology, 99(15), 6780-6792. https://doi.org/10.1016/j.biortech.2008.01.045

Chazarenc, F., Gagnon, V., Comeau, Y., \& Brisson, J. (2009). Effect of plant and artificial aeration on solids accumulation and biological activities in constructed wetlands. Ecological Engineering, 35(6), 1005-1010. https://doi.org/10.1016/j.ecoleng.2008.07.008

Chen, H., Zou, J., Cui, J., Nie, M., \& Fang, C. (2018). Wetland drying increases the temperature sensitivity of soil respiration. Soil Biology and Biochemistry, 120, 24-27. https://doi.org/10.1016/j.soilbio.2018.01.035

Chen, X., Zhu, H., Yan, B., Shutes, B., Xing, D., Banuelos, G., ... Wang, X. (2020). Greenhouse gas emissions and wastewater treatment performance by three plant species in subsurface flow constructed wetland mesocosms. Chemosphere, 239, 124795. https://doi.org/10.1016/j.chemosphere.2019.124795

Choudhary, A. K., Kumar, S., \& Sharma, C. (2011). Constructed wetlands: an approach for wastewater treatment. Elixir Pollution, 37(8), 3666-3672.

Choudhury, M. I., Segersten, J., Hellman, M., McKie, B. G., Hallin, S., \& Ecke, F. (2019). Importance of plant species for nitrogen removal using constructed floating wetlands in a cold climate. Ecological Engineering, 138, 126-132. https://doi.org/10.1016/j.ecoleng.2019.07.012

Comino, E., Riggio, V., \& Rosso, M. (2011). Mountain cheese factory wastewater treatment with the use of a hybrid constructed wetland. Ecological Engineering, 37(11), 1673-1680. https://doi.org/10.1016/j.ecoleng. 2011.06.048

Cronk, J. K. (1996). Constructed wetlands to treat wastewater from dairy and swine operations: A review. Agriculture, Ecosystems \& Environment, 58(2-3), 97-114. https://doi.org/10.1016/0167-8809(96)01024-9

De Vries, J. (1972). Soil filtration of wastewater effluent and the mechanism of pore clogging. Journal Water Pollution Control Federation, 44(4), 565-573.

Dunne, E. J., Culleton, N., O’Donovan, G., Harrington, R., \& Olsen, A. E. (2005). An integrated constructed wetland to treat contaminants and nutrients from dairy farmyard dirty water. Ecological Engineering, 24(3), 219-232. https://doi.org/10.1016/j.ecoleng.2004.11.010

ECCC (Environment and Climate Change Canada). (2021). Historical Climate Data. Retrieved from https://climate.weather.gc.ca/index_e.html 
Faulwetter, J. L., Gagnon, V., Sundberg, C., Chazarenc, F., Burr, M. D., Brisson, J., ... Stein, O. R. (2009). Microbial processes influencing performance of treatment wetlands: A review. Ecological Engineering, 35(6), 987-1004. https://doi.org/10.1016/j.ecoleng.2008.12.030

Fitch, M. W. (2014). Constructed Wetlands. In S. Ahuja (Ed.), Comprehensive Water Quality and Purification (pp. 268-295). Waltham: Elsevier.

Freeman, C., Lock, M. A., Hughes, S., Reynolds, B., \& Hudson, J. A. (1997). Nitrous oxide emissions and the use of wetlands for water quality amelioration. Environmental Science \& Technology, 31(8), 2438-2440. https://doi.org/10.1021/es9604673

Gao, D.-W., \& Hu, Q. (2012). Bio-contact oxidation and greenhouse-structured wetland system for rural sewage recycling in cold regions: A full-scale study. Ecological Engineering, 49, 249-253. https://doi.org/10.1016/ j.ecoleng.2012.08.012

Garfi, M., Pedescoll, A., Becares, E., Hijosa-Valsero, M., Sidrach-Cardona, R., \& Garcia, J. (2012). Effect of climatic conditions, season and wastewater quality on contaminant removal efficiency of two experimental constructed wetlands in different regions of Spain. Science of the Total Environment, 437, 61-67. https://doi.org/10.1016/j.scitotenv.2012.07.087

Gorra, R., Freppaz, M., Zanini, E., \& Scalenghe, R. (2014). Mountain dairy wastewater treatment with the use of a 'irregularly shaped' constructed wetland (Aosta Valley, Italy). Ecological Engineering, 73, 176-183. https://doi.org/10.1016/j.ecoleng.2014.09.013

Gottschall, N., Boutin, C., Crolla, A., Kinsley, C., \& Champagne, P. (2007). The role of plants in the removal of nutrients at a constructed wetland treating agricultural (dairy) wastewater, Ontario, Canada. Ecological Engineering, 29(2), 154-163. https://doi.org/10.1016/j.ecoleng.2006.06.004

Grebenshchykova, Z., Brisson, J., Chazarenc, F., \& Comeau, Y. (2020). Two-year performance of single-stage vertical flow treatment wetlands planted with willows under cold-climate conditions. Ecological Engineering, 153, 105912. https://doi.org/10.1016/j.ecoleng.2020.105912

Gunes, K., Tuncsiper, B., Ayaz, S., \& Drizo, A. (2012). The ability of free water surface constructed wetland system to treat high strength domestic wastewater: A case study for the Mediterranean. Ecological Engineering, 44, 278-284. https://doi.org/10.1016/j.ecoleng.2012.04.008

Halverson, N. (2004). Review of Constructed Subsurface Flow vs Surface Flow Wetlands. United States. Retrieved from https://www.osti.gov/servlets/purl/835229-ilhjDG/native

Harada, J., Inoue, T., Kato, K., Uraie, N., \& Sakuragi, H. (2015). Performance evaluation of hybrid treatment wetland for six years of operation in cold climate. Environmental Science and Pollution Research, 22(17), 12861-12869. https://doi.org/10.1007/s11356-014-3843-2

Harrington, R., \& McInnes, R. (2009). Integrated Constructed Wetlands (ICW) for livestock wastewater management. Bioresource Technology, 100(22), 5498-5505. https://doi.org/10.1016/j.biortech.2009.06.007

Hijosa-Valsero, M., Sidrach-Cardona, R., Martin-Villacorta, J., \& Becares, E. (2010). Optimization of performance assessment and design characteristics in constructed wetlands for the removal of organic matter. Chemosphere, 81(5), 651-657. https://doi.org/10.1016/j.chemosphere.2010.08.010

Huang, J., Cai, W., Zhong, Q., \& Wang, S. (2013). Influence of temperature on micro-environment, plant eco-physiology and nitrogen removal effect in subsurface flow constructed wetland. Ecological Engineering, 60, 242-248. https://doi.org/10.1016/j.ecoleng.2013.07.023

Hunt, P. G., \& Poach, M. E. (2001). State of the art for animal wastewater treatment in constructed wetlands. Water Science and Technology, 44(11-12), 19-25. https://doi.org/https://doi.org/10.2166/wst.2001.0805

Ioannidou, V. G., \& Pearson, J. M. (2018). Hydraulic and design parameters in full-scale constructed wetlands and treatment units: six case studies. Environmental Processes, 5(S1), 5-22. https://doi.org/10.1007/s40710018-0313-8

Jenssen, P. D., \& Mander, è. (2002). Advances in Ecological Sciences: Natural wetlands for wastewater treatment in cold climates (Vol. 12). Southampton: WIT Press.

Jenssen, P. D., Maehlum, T., Krogstad, T., \& Vrale, L. (2005). High performance constructed wetlands for cold climates. Journal of Environmental Science and Health Part A-Toxic/Hazard Substances \& Environmental Engineering, 40(6-7), 1343-1353. https://doi.org/10.1081/ese-200055846 
Ji, H., Han, J., Xue, J., Hatten, J. A., Wang, M., Guo, Y., \& Li, P. (2020). Soil organic carbon pool and chemical composition under different types of land use in wetland: Implication for carbon sequestration in wetlands. Science of the Total Environment, 716, 136996. https://doi.org/10.1016/j.scitotenv.2020.136996

Jing, S. R., \& Lin, Y. F. (2004). Seasonal effect on ammonia nitrogen removal by constructed wetlands treating polluted river water in southern Taiwan. Environmental Pollution, 127(2), 291-301. https://doi.org/10.1016/ s0269-7491(03)00267-7

Joabsson, A., Christensen, T. R., \& Wallen, B. (1999). Vascular plant controls on methane emissions from northern peatforming wetlands. Trends in Ecology \& Evolution, 14(10), 385-388. https://doi.org/10.1016/ s0169-5347(99)01649-3

Johnston, C. A. (1991). Sediment and nutrient retention by freshwater wetlands: Effects on surface water quality. Critical Reviews in Environmental Control, 21(5-6), 491-565. https://doi.org/10.1080/10643389109388425

Kadlec, R. H., \& Reddy, K. R. (2001). Temperature effects in treatment wetlands. Water Environment Research, 73(5), 543-557. https://doi.org/10.2175/106143001x139614

Kadlec, R. H., Pries, J., \& Mustard, H. (2007). Muskrats (Ondatra zibethicus) in treatment wetlands. Ecological Engineering, 29(2), 143-153. https://doi.org/10.1016/j.ecoleng.2006.06.008

Kato, K., Inoue, T., Ietsugu, H., Koba, T., Sasaki, H., Miyaji, N., ... Nagasawa, T. (2013). Performance of six multi-stage hybrid wetland systems for treating high-content wastewater in the cold climate of Hokkaido, Japan. Ecological Engineering, 51, 256-263. https://doi.org/10.1016/j.ecoleng.2012.12.002

Kaushal, S. S., Mayer, P. M., Vidon, P. G., Smith, R. M., Pennino, M. J., Newcomer, T. A., ... Belt, K. T. (2014). Land use and climate variability amplify carbon, nutrient, and contaminant pulses: A review with management implications. JAWRA Journal of the American Water Resources Association, 50(3), 585-614. https://doi.org/10.1111/jawr.12204

Kern, J., Idler, C., \& Carlow, G. (2000). Removal of fecal coliforms and organic matter from dairy farm wastewater in a constructed wetland under changing climate conditions. Journal of Environmental Science and Health, Part A, 35(8), 1445-1461. https://doi.org/10.1080/10934520009377046

Klein, E., Berg, E. E., \& Dial, R. (2005). Wetland drying and succession across the Kenai Peninsula Lowlands, south-central Alaska. Canadian Journal of Forest Research, 35(8), 1931-1941. https://doi.org/10.1139/ $\mathrm{x} 05-129$

Knight, R. L., Kadlec, R. H., \& Ohlendorf, H. M. (1999). The use of treatment wetlands for petroleum industry effluents. Environmental Science \& Technology, 33(7), 973-980. https://doi.org/10.1021/es980740w

Knight, R. L., Payne, V. W. E., Borer, R. E., Clarke, R. A., \& Pries, J. H. (2000). Constructed wetlands for livestock wastewater management. Ecological Engineering, 15(1-2), 41-55. https://doi.org/10.1016/ s0925-8574(99)00034-8

Koponen, H. T., \& Martikainen, P. J. (2004). Soil water content and freezing temperature affect freeze-thaw related $\mathrm{N}_{2} \mathrm{O}$ production in organic soil. Nutrient Cycling in Agroecosystems, 69(3), 213-219. https://doi.org/ 10.1023/b:Fres.0000035172.37839.24

Koskiaho, J., Ekholm, P., Räty, M., Riihimäki, J., \& Puustinen, M. (2003). Retaining agricultural nutrients in constructed wetlands-experiences under boreal conditions. Ecological Engineering, 20(1), 89-103. https://doi.org/10.1016/s0925-8574(03)00006-5

Kotti, I. P., Gikas, G. D., \& Tsihrintzis, V. A. (2010). Effect of operational and design parameters on removal efficiency of pilot-scale FWS constructed wetlands and comparison with HSF systems. Ecological Engineering, 36(7), 862-875. https://doi.org/10.1016/j.ecoleng.2010.03.002

Lee, C.-g., Fletcher, T. D., \& Sun, G. (2009). Nitrogen removal in constructed wetland systems. Engineering in Life Sciences, 9(1), 11-22. https://doi.org/10.1002/elsc.200800049

Lee, S., Maniquiz-Redillas, M. C., Choi, J., \& Kim, L. H. (2014). Nitrogen mass balance in a constructed wetland treating piggery wastewater effluent. Journal of Environmental Sciences (China), 26(6), 1260-1266. https://doi.org/10.1016/S1001-0742(13)60597-5

Li, F., Lu, L., Zheng, X., \& Zhang, X. (2014). Three-stage horizontal subsurface flow constructed wetlands for organics and nitrogen removal: Effect of aeration. Ecological Engineering, 68, 90-96. https://doi.org/ 10.1016/j.ecoleng.2014.03.025 
Li, Y., Zhang, Y., \& Zhang, X. (2011). Heat preservation of subsurface flow constructed wetland in cold area in winter and its operation effect. Procedia Environmental Sciences, 10, 2182-2188. https://doi.org/10.1016/ j.proenv.2011.09.342

Linquist, B. A., Adviento-Borbe, M. A., Pittelkow, C. M., van Kessel, C., \& van Groenigen, K. J. (2012). Fertilizer management practices and greenhouse gas emissions from rice systems: A quantitative review and analysis. Field Crops Research, 135, 10-21. https://doi.org/10.1016/j.fcr.2012.06.007

Liu, C., Xu, K., Inamori, R., Ebie, Y., Liao, J., \& Inamori, Y. (2009). Pilot-scale studies of domestic wastewater treatment by typical constructed wetlands and their greenhouse gas emissions. Frontiers of Environmental Science \& Engineering in China, 3(4), 477-482. https://doi.org/10.1007/s11783-009-0155-8

Liu, J. J., Dong, B., Guo, C. Q., Liu, F. P., Brown, L., \& Li, Q. (2016). Variations of effective volume and removal rate under different water levels of constructed wetland. Ecological Engineering, 95, 652-664. https://doi.org/10.1016/j.ecoleng.2016.06.122

Llorens, E., Matamoros, V., Domingo, V., Bayona, J. M., \& Garcia, J. (2009). Water quality improvement in a full-scale tertiary constructed wetland: effects on conventional and specific organic contaminants. Science of the Total Environment, 407(8), 2517-2524. https://doi.org/10.1016/j.scitotenv.2008.12.042

Mæhlum, T., \& Jenssen, P. (2003). Design and performance of integrated subsurface flow wetlands in a cold climate. In U. Mander and P. Jenssen (Eds.), Constructed Wetlands for Wastewater Treatment in Cold Climates (pp. 69-86). Southampton: WIT Press.

Mæhlum, T., \& Stålnacke, P. (1999). Removal efficiency of three cold-climate constructed wetlands treating domestic wastewater: effects of temperature, seasons, loading rates and input concentrations. Water Science and Technology, 40(3), 273-281.

Maine, M. A., Sune, N., Hadad, H., Sanchez, G., \& Bonetto, C. (2007). Removal efficiency of a constructed wetland for wastewater treatment according to vegetation dominance. Chemosphere, 68(6), 1105-1113. https://doi.org/10.1016/j.chemosphere.2007.01.064

Mander, Ü., Maddison, M., Soosaar, K., \& Karabelnik, K. (2011). The impact of pulsing hydrology and fluctuating water table on greenhouse gas emissions from constructed wetlands. Wetlands, 31(6), 1023-1032. https://doi.org/10.1007/s13157-011-0218-z

Mantovi, P., Marmiroli, M., Maestri, E., Tagliavini, S., Piccinini, S., \& Marmiroli, N. (2003). Application of a horizontal subsurface flow constructed wetland on treatment of dairy parlor wastewater. Bioresource Technology, 88(2), 85-94. https://doi.org/10.1016/s0960-8524(02)00291-2

Mayer, T., \& Kennedy, G. (2002). Natural and constructed wetlands in Canada: An overview. Water Quality Research Journal, 37(2), 295-325. https://doi.org/10.2166/wqrj.2002.020

McCauley, L. A., Anteau, M. J., van der Burg, M. P., \& Wiltermuth, M. T. (2015). Land use and wetland drainage affect water levels and dynamics of remaining wetlands. Ecosphere, 6(6), 1-22. https://doi.org/ 10.1890/es14-00494.1

McKenna, O. P., Osorio, J. M., Behrman, K. D., Doro, L., \& Mushet, D. M. (2020). Development of a novel framework for modeling field-scale conservation effects of depressional wetlands in agricultural landscapes. Journal of Soil and Water Conservation, 75(6), 695-703. https://doi.org/10.2489/jswc.2020.00096

Mejia-Franco, J., Kinsley, C., \& Delatolla, R. (2020). Performance and kinetics of a pond-constructed wetland system treating beef manure pile and exercise yard runoff in Eastern Ontario. Water, 12(1). https://doi.org/10.3390/w12010168

Meng-Liang, Y., \& Han, Y. C. (2019). New solution to apply constructed wetland technology in cold climate. IOP Conference Series: Earth and Environmental Science, 371. https://doi.org/10.1088/1755-1315/371/3/ 032050

Miao, Y., Song, C., Wang, X., Sun, X., Meng, H., \& Sun, L. (2012). Greenhouse gas emissions from different wetlands during the snow-covered season in Northeast China. Atmospheric Environment, 62, 328-335. https://doi.org/10.1016/j.atmosenv.2012.08.036

Mitsch, W. J., Nahlik, A., Wolski, P., Bernal, B., Zhang, L., \& Ramberg, L. (2009). Tropical wetlands: seasonal hydrologic pulsing, carbon sequestration, and methane emissions. Wetlands Ecology and Management, 18(5), 573-586. https://doi.org/10.1007/s11273-009-9164-4 
Mitsch, W. J., Zhang, L., Waletzko, E., \& Bernal, B. (2014). Validation of the ecosystem services of created wetlands: Two decades of plant succession, nutrient retention, and carbon sequestration in experimental riverine marshes. Ecological Engineering, 72, 11-24. https://doi.org/10.1016/j.ecoleng.2014.09.108

Mortsch, L. D. (1998). Assessing the impact of climate change on the Great Lakes Shoreline Wetlands. Climatic Change, 40(2), 391-416. https://doi.org/10.1023/a:1005445709728

Munoz, P., Drizo, A., \& Hession, W. (2006). Flow patterns of dairy wastewater constructed wetlands in a cold climate. Water Research, 40(17), 3209-3218. https://doi.org/10.1016/j.watres.2006.06.036

Mustafa, A., Scholz, M., Harrington, R., \& Carroll, P. (2009). Long-term performance of a representative integrated constructed wetland treating farmyard runoff. Ecological Engineering, 35(5), 779-790. https://doi.org/10.1016/j.ecoleng.2008.12.008

Nelson, M., Finn, M., Wilson, C., Zabel, B., van Thillo, M., Hawes, P., \& Fernandez, R. (1999). Bioregenerative recycling of wastewater in Biosphere 2 using a constructed wetland: 2-year results. Ecological Engineering, 13(1-4), 189-197. https://doi.org/10.1016/s0925-8574(98)00099-8

Newman, J. M., Clausen, J. C., \& Neafsey, J. A. (1999). Seasonal performance of a wetland constructed to process dairy milkhouse wastewater in Connecticut. Ecological Engineering, 14(1-2), 181-198. https://doi.org/10.1016/s0925-8574(99)00028-2

O'Geen, A. T., Budd, R., Gan, J., Maynard, J. J., Parikh, S. J., \& Dahlgren, R. A. (2010). Mitigating Nonpoint Source Pollution in Agriculture with Constructed and Restored Wetlands. In D. L. Sparks (Ed.), Advances in Agronomy (Vol. 108, pp. 1-76). Academic Press.

Ouellet-Plamondon, C., Chazarenc, F., Comeau, Y., \& Brisson, J. (2006). Artificial aeration to increase pollutant removal efficiency of constructed wetlands in cold climate. Ecological Engineering, 27(3), 258-264. https://doi.org/10.1016/j.ecoleng.2006.03.006

Pedescoll, A., Corzo, A., Álvarez, E., Puigagut, J., \& García, J. (2011). Contaminant removal efficiency depending on primary treatment and operational strategy in horizontal subsurface flow treatment wetlands. Ecological Engineering, 37(2), 372-380. https://doi.org/10.1016/j.ecoleng.2010.12.011

Pennock, D., Yates, T., Bedard-Haughn, A., Phipps, K., Farrell, R., \& McDougal, R. (2010). Landscape controls on $\mathrm{N}_{2} \mathrm{O}$ and $\mathrm{CH}_{4}$ emissions from freshwater mineral soil wetlands of the Canadian Prairie Pothole region. Geoderma, 155(3-4), 308-319. https://doi.org/10.1016/j.geoderma.2009.12.015

Petticrew, E. L., \& Kalff, J. (1992). Water flow and clay retention in submerged macrophyte beds. Canadian Journal of Fisheries and Aquatic Sciences, 49(12), 2483-2489. https://doi.org/10.1139/f92-274

Phipps, R. G., \& Crumpton, W. G. (1994). Factors affecting nitrogen loss in experimental wetlands with different hydrologic loads. Ecological Engineering, 3(4), 399-408. https://doi.org/10.1016/0925-8574 (94)00009-3

Reuter, J. E., Djohan, T., \& Goldman, C. R. (1992). The use of wetlands for nutrient removal from surface runoff in a cold climate region of California-results from a newly constructed wetland at lake tahoe. Journal of Environmental Management, 36(1), 35-53. https://doi.org/10.1016/s0301-4797(05)80100-8

Rozema, E. R., Rozema, L. R., \& Zheng, Y. (2016). A vertical flow constructed wetland for the treatment of winery process water and domestic sewage in Ontario, Canada: Six years of performance data. Ecological Engineering, 86, 262-268. https://doi.org/10.1016/j.ecoleng.2015.11.006

Salimi, S., Almuktar, S., \& Scholz, M. (2021). Impact of climate change on wetland ecosystems: A critical review of experimental wetlands. Journal of Environmental Management, 286, 112160. https://doi.org/ 10.1016/j.jenvman.2021.112160

Schaafsma, J. A., Baldwin, A. H., \& Streb, C. A. (1999). An evaluation of a constructed wetland to treat wastewater from a dairy farm in Maryland, USA. Ecological Engineering, 14(1-2), 199-206. https://doi.org/ 10.1016/s0925-8574(99)00029-4

Sharma, P. K., Takashi, I., Kato, K., Ietsugu, H., Tomita, K., \& Nagasawa, T. (2013). Seasonal efficiency of a hybrid sub-surface flow constructed wetland system in treating milking parlor wastewater at northern Hokkaido. Ecological Engineering, 53, 257-266. https://doi.org/10.1016/j.ecoleng.2012.12.054

Sievers, D. M. (1997). Performance of four constructed wetlands treating anaerobic swine lagoon effluents. Transactions of the ASAE, 40(3), 769-775. https://doi.org/10.13031/2013.21308 
Sindilariu, P.-D., Schulz, C., \& Reiter, R. (2007). Treatment of flow-through trout aquaculture effluents in a constructed wetland. Aquaculture, 270(1-4), 92-104. https://doi.org/10.1016/j.aquaculture.2007.03.006

Smith, E. L., Kellman, L., \& Brenton, P. (2019). Restoration of on-farm constructed wetland systems used to treat agricultural wastewater. Journal of Agricultural Science, 11, 1-12. https://doi.org/ $10.5539 /$ jas.v11n4p1

Smith, E., Gordon, R., Madani, A., \& Stratton, G. (2005a). Cold climate hydrological flow characteristics of constructed wetlands. Canadian Biosystems Engineering, 47, 1.1-1.7.

Smith, E., Gordon, R., Madani, A., \& Stratton, G. (2005b). Pathogen removal by agricultural constructed wetlands in cold climates. Journal of Environmental Informatics, 6(1), 46-50. https://doi.org/10.3808/ jei.200500054

Smith, E., Gordon, R., Madani, A., \& Stratton, G. (2006). Year-round treatment of dairy wastewater by constructed wetlands in Atlantic Canada. Wetlands, 26(2), 349-357. https://doi.org/10.1672/0277-5212 (2006)26[349:Ytodwb]2.0.Co;2

Song, Z., Zheng, Z., Li, J., Sun, X., Han, X., Wang, W., \& Xu, M. (2006). Seasonal and annual performance of a full-scale constructed wetland system for sewage treatment in China. Ecological Engineering, 26(3), 272-282. https://doi.org/10.1016/j.ecoleng.2005.10.008

Steinmann, C. R., Weinhart, S., \& Melzer, A. (2003). A combined system of lagoon and constructed wetland for an effective wastewater treatment. Water Research, 37(9), 2035-2042. https://doi.org/10.1016/S0043-1354 (02)00441-4

Tanner, C. C., \& Sukias, J. P. (1995). Accumulation of organic solids in gravel-bed constructed wetlands. Water Science and Technology, 32(3), 229-239. https://doi.org/10.1016/0273-1223(95)00624-9

Taylor, C. R., Hook, P. B., Stein, O. R., \& Zabinski, C. A. (2011). Seasonal effects of 19 plant species on COD removal in subsurface treatment wetland microcosms. Ecological Engineering, 37(5), 703-710. https://doi.org/10.1016/j.ecoleng.2010.05.007

Teepe, R., Brumme, R., \& Beese, F. (2001). Nitrous oxide emissions from soil during freezing and thawing periods. Soil Biology and Biochemistry, 33(9), 1269-1275. https://doi.org/10.1016/s0038-0717(01)00084-0

Thorén, A.-K., Legrand, C., \& Tonderski, K. S. (2004). Temporal export of nitrogen from a constructed wetland: influence of hydrology and senescing submerged plants. Ecological Engineering, 23(4-5), 233-249. https://doi.org/10.1016/j.ecoleng.2004.09.007

Tunçsiper, B., Drizo, A., \& Twohig, E. (2015). Constructed wetlands as a potential management practice for cold climate dairy effluent treatment-VT, USA. CATENA, 135, 184-192. https://doi.org/10.1016/j.catena. 2015.07.028

Vymazal, J. (2005). Horizontal sub-surface flow and hybrid constructed wetlands systems for wastewater treatment. Ecological Engineering, 25(5), 478-490. https://doi.org/10.1016/j.ecoleng.2005.07.010

Vymazal, J. (2017). The use of constructed wetlands for nitrogen removal from agricultural drainage: A review. Scientia Agriculturae Bohemica, 48(2), 82-91.

Vymazal, J., \& Březinová, T. (2014). Long term treatment performance of constructed wetlands for wastewater treatment in mountain areas: Four case studies from the Czech Republic. Ecological Engineering, 71, 578-583. https://doi.org/10.1016/j.ecoleng.2014.07.075

Vymazal, J., \& Dvorakova Brezinova, T. (2018). Treatment of a small stream impacted by agricultural drainage in a semi-constructed wetland. Science of the Total Environment, 643, 52-62. https://doi.org/10.1016/ j.scitotenv.2018.06.148

Wang, F., Liu, Y., Ma, Y., Wu, X., \& Yang, H. (2012). Characterization of nitrification and microbial community in a shallow moss constructed wetland at cold temperatures. Ecological Engineering, 42, 124-129. https://doi.org/10.1016/j.ecoleng.2012.01.006

Wang, J., Song, C., Miao, Y., \& Meng, H. (2013). Greenhouse gas emissions from southward transplanted wetlands during freezing-thawing periods in Northeast China. Wetlands, 33(6), 1075-1081. https://doi.org/ $10.1007 / \mathrm{s} 13157-013-0463-4$ 
Wang, M., Zhang, D. Q., Dong, J. W., \& Tan, S. K. (2017). Constructed wetlands for wastewater treatment in cold climate-A review. Journal of Environmental Sciences (China), 57, 293-311. https://doi.org/10.1016/ j.jes.2016.12.019

Wang, Q., Xie, H., Zhang, J., Liang, S., Ngo, H. H., Guo, W., ... Li, H. (2015). Effect of plant harvesting on the performance of constructed wetlands during winter: radial oxygen loss and microbial characteristics. Environmental Science and Pollution Research, 22(10), 7476-7484. https://doi.org/10.1007/s11356-0143966-5

Wei, Y., Zhang, M., Cui, L., Pan, X., Liu, W., Li, W., \& Lei, Y. (2020). Winter decomposition of emergent macrophytes affects water quality under ice in a temperate shallow lake. Water, 12(9). https://doi.org/ $10.3390 /$ w 12092640

Werker, A. G., Dougherty, J. M., McHenry, J. L., \& Van Loon, W. A. (2002). Treatment variability for wetland wastewater treatment design in cold climates. Ecological Engineering, 19(1), 1-11. https://doi.org/10.1016/ s0925-8574(02)00016-2

Wood, S. L., Wheeler, E. F., Berghage, R. D., \& Graves, R. E. (1999). Temperature effects on wastewater nitrate removal in laboratory-scale constructed wetlands. Transactions of the ASAE, 42(1), 185-190. https://doi.org/10.13031/2013.13195

Wu, S., Austin, D., Liu, L., \& Dong, R. (2011). Performance of integrated household constructed wetland for domestic wastewater treatment in rural areas. Ecological Engineering, 37(6), 948-954. https://doi.org/ 10.1016/j.ecoleng.2011.02.002

Wu, S., Kuschk, P., Brix, H., Vymazal, J., \& Dong, R. (2014). Development of constructed wetlands in performance intensifications for wastewater treatment: a nitrogen and organic matter targeted review. Water Research, 57, 40-55. https://doi.org/10.1016/j.watres.2014.03.020

Zhang, L., Mu, L., Xiong, Y., Xi, B., Li, G., \& Li, C. (2015). The development of a natural heating technology for constructed wetlands in cold climates. Ecological Engineering, 75, 51-60. https://doi.org/10.1016/ j.ecoleng.2014.11.025

Zhang, X., Inoue, T., Kato, K., Izumoto, H., Harada, J., Wu, D., ... Sugawara, Y. (2017). Multi-stage hybrid subsurface flow constructed wetlands for treating piggery and dairy wastewater in cold climate. Environmental Technology, 38(2), 183-191. https://doi.org/10.1080/09593330.2016.1187206

Zhu, D., Sun, C., Zhang, H., Wu, Z., Jia, B., \& Zhang, Y. (2012). Roles of vegetation, flow type and filled depth on livestock wastewater treatment through multi-level mineralized refuse-based constructed wetlands. Ecological Engineering, 39, 7-15. https://doi.org/10.1016/j.ecoleng.2011.11.002

\begin{abstract}
Abbreviations
Ammonia $\left(\mathrm{NH}_{3}\right)$, ammonium-nitrogen $\left(\mathrm{NH}_{4}{ }^{+}-\mathrm{N}\right)$, biological oxygen demand (BOD), carbon $(\mathrm{C})$, carbon dioxide $\left(\mathrm{CO}_{2}\right)$, chemical oxygen demand $(\mathrm{COD})$, chemical oxygen demand by dichromate $\left(\mathrm{COD}_{\mathrm{Cr}}\right)$, constructed wetlands (CWs), dissolved oxygen (DO), greenhouse gas (GHG), horizontal flow (HF), hydraulic loading rate (HLR), hydraulic retention time (HRT), methane $\left(\mathrm{CH}_{4}\right)$, nitrate-nitrogen $\left(\mathrm{NO}_{3}{ }^{-} \mathrm{N}\right)$, nitrite $\left(\mathrm{NO}_{2}{ }^{-}\right)$, nitrogen $(\mathrm{N})$, nitrous oxide $\left(\mathrm{N}_{2} \mathrm{O}\right)$, oxygen $\left(\mathrm{O}_{2}\right)$, phosphorus $(\mathrm{P})$, retention time (RT), subsurface flow (SSF), surface flow (SF), total-nitrogen (TN), total phosphorous (TP), total suspended solids (TSS), vertical flow (VF).
\end{abstract}

\title{
Copyrights
}

Copyright for this article is retained by the author(s), with first publication rights granted to the journal.

This is an open-access article distributed under the terms and conditions of the Creative Commons Attribution license (http://creativecommons.org/licenses/by/4.0/). 